\title{
CERTEZA Y VERDAD EN EL DERECHO ${ }^{1}$
}

\author{
Agustín Luna Serrano \\ Catedrático de Derecho Civil y Profesor de Teoría del Derecho \\ Facultad de Derecho - ESADE \\ Universidad Ramón Llull
}

Sumario. 1. La posible escisión entre certeza y verdad. 1.1. Unas referencias doctrinales como punto de partida. 1.2. Las certezas públicas de las verdades oficiales. 1.3. Consistencia y variedad de las verdades oficiales. 1.4. La justificada asunción instrumental de las verdades oficiales. 2. La certeza de las verdades oficiales. 2.1. Breves indicaciones taxonómicas. 2.2. Las verdades presuntas. 2.3. Las verdades presupuestas. 2.4. Las verdades aparentes. 2.5. Las verdades simuladas. 2.6. Las verdades fiduciarias. 2.7. Las verdades ficticias. 2.8. Las verdades falsas. 3. Apreciaciones Conclusivas. 3.1. La razonable divergencia entre certeza y verdad. 3.2. Colofón.

\section{LA POSIBLE ESCISIÓN ENTRE CERTEZA Y VERDAD.}

\subsection{Unas referencias doctrinales como punto de partida.}

Un notable filósofo jurista de nuestro tiempo, italiano de indudable ascendencia hispana, Flavio López de Oñate, ha señalado con precisión, en un libro devenido famoso, que cada uno de los individuos recibe del ordenamiento, impuesto por la autoridad, «la certeza de sí mismo y la garantía de su acción, que es garantía de su individualidad, de su realidad y de su persona» ${ }^{2}$, de manera que,

${ }^{1}$ Se trata del texto, completado con notas, de la lectio doctoralis pronunciada, de manera resumida, en la Universidad de Almería el día 11 de mayo de 2012.

${ }^{2}$ Se hace referencia a la contribución, enseguida alabada por los mayores juristas del tiempo de su aparición, de LÓPEZ de OÑATE, La certezza del diritto (Nuova edizione riveduta, in aggiunta saggi di G. Capograssi, P. Calamandrei, F. Carnelutti e P. Fedele; a cura di G. Astuti e con appendice di M. Corsale), Milano, Giuffrè, 1968, pág. 114. La primera edición del libro apareció en Roma, Tipografica Consorzio Nazionale, 1942, y la edición utilizada se inscribe en la prestigiosa colección «Civiltà del diritto», vol. 19, de la citada casa editorial milanesa. Hay trad. esp. de Santís Melendo y Ayera Redin, Buenos Aires, Ediciones Jurídicas Europa-América, 1953.

La obra, por la fecha de su aparición, se sitúa en el contexto de la crisis social y política del momento y de su repercusión en la crisis y consiguiente incerteza del derecho y constituye una defensa decidida de la certeza del mismo que se proyecta en la seguridad que de ella deriva para el individuo (pág. 47), en cuanto que la certeza constituye - «savoir c'est prèvoir»)- la garantía de la acción individual, a cuyo efecto se refiere a la salus ciceroniana y a la conocida sentencia de que legum omnes servi sumus ut liberi esse possimus.

Es notable la modernidad del libro de LOPEZ DE OÑATE que, con referencia a su tiempo, habla de las amenazas de hecho que atentan a la certeza del derecho y que consisten, a su juicio, 
en cuanto que «la exigencia más viva de defensa del sujeto es su individualidad, precisa, singular e irreductible» ${ }^{3}$, «la exigencia de certeza del derecho es por eso la más ineliminable exigencia ética, de su específica eticidad, que el derecho encuentra en nuestra época ${ }^{4}$, por lo que, al atribuir el derecho facultades a cada individuo, le otorga también «la certeza de que su voluntad puede ser realmente querida $»^{5}$ y entonces «el sujeto, con la certeza, conquista la seguridad» ${ }^{6}$.

en la falta de norma, en su ambigüedad y oscuridad (pág. 67), en las lagunas legales (págs. 68 s.), en la frecuente mutación de las leyes (pág. 70) y en la hipertrofia de las mismas (págs. 71 s.). Es significativo al respecto un pasaje de la obra que fácilmente se puede relacionar con el nihilismo jurídico, que, como natural derivación del positivismo, deja sentir fuertemente su influencia en la actualidad: señala, en efecto, el autor que el ciudadano «ya no se encuentra frente a la ley como voluntad igual y constante, es decir, cierta, sino frente a una voluntad continuamente renovada e imprevisible que se califica como derecho» (pág. 40).

${ }^{3}$ Cfr. LóPeZ de Oñate, La certezza del diritto cit., pág. 114.

Esta dimensión personalista de la certeza se expresa acertadamente por Laporta, en Laporta, Ruiz Manero y Rodilla, Certeza y predecibilidad de las relaciones jurídicas, Madrid, Fundación Coloquio Jurídico Europeo, 2009, pág. 56, al significar que la certeza, frente a la incerteza o incertidumbre jurídicas, es «poder saber con precisión lo que jurídicamente se es», «poder saber qué sujeto de derecho se es», «poder conocer el alcance del propio estatus en una relación dada» o «poder determinar el contenido y los límites de los propios derechos y deberes» y al enlazar todo ello (pág. 59) con la idea de «autonomía personal».

${ }^{4}$ Cfr. LóPeZ de OÑate, La certezza del diritto cit., pág. 114. Por eso se ha podido afirmar, por un filósofo del derecho contemporáneo, que «la predecibilidad de las consecuencias jurídicas de los propios actos, en que la certeza del derecho consiste, es posible en tanto en cuanto sea posible un razonamiento sobre condiciones y consecuencias, sobre premisas y conclusiones: razonamiento, ciertamente, no de absoluta necesidad, 'demostrativo', sino por lo menos de verosimilitud o de probabilidad, 'argumentativo'»: cfr. FAssò, Il giudice e la realtà sociale, en Società, legge e ragione, Milano, Giuffrè, 1974, pág. 19.

Si en los países de «civil law» la certeza se realiza mediante la ley, respecto de los de «common law» es de recordar que «la vincolabilità del precedente»-que trasciende normativamente, por la extensión de su ratio decidenci a los casos análogos, en función de la obligada igualdad (aequitas, en cuanto que «equality before the law») - «realizza, o concorre a realizzare, anche il valore della certezza del diritto»: cfr. Donat, «Rule of law, common law»: lineamenti, Milano, Giuffrè, 2010, págs. 16 ss.

${ }^{5}$ Cfr. LóPez de Oñate, La certezza del diritto cit., pág. 115.

${ }^{6}$ Cfr. LóPEZ DE OÑate, La certezza del diritto cit., pág. 115. El autor recuerda a este propósito una significativa sentencia de Gravina, según la cual sub incerto enim iure nemo bonorum aut animae securus vivit.

Los estudios más significativos sobre la obra de Lopez de Oñate suelen subrayar este valor tranquilizante de la certeza del derecho respecto de las actividades de los particulares que operan teniendo en cuenta las reglas del mismo. En su elogioso comentario al libro de referencia, CALAMANDREI, «La certezza del diritto e la responsabilità della dottrina», Rivista di diritto commerciale, 1942, I, págs. 341 ss. (luego vuelto a publicar en 
Ahora bien, otro asimismo notable filósofo, el napolitano Giambattista Vico (1668-1744), que ya había expresado en alguna ocasión la profunda reflexión de que cuando los hombres no pueden alcanzar la verdad se atienen a lo cierto ${ }^{7}$, vino también a afirmar, en una línea argumental que puede superponerse, que certum ab auctoritate est mientras que verum (est) a ratione, añadiendo a esta consideración la de que auctoritas cum ratione omnino pugnare non potest, nam ita non leges essent, sed mostra legum ${ }^{8}$, que ha sido considerada por algunos como contradictoria con la anterior afirmación. Es posible, sin embargo, según creo, coordinar con cierta facilidad los dos pasajes relativos al derecho acabados de transcribir, puesto que, usando las mismas palabras latinas en su traducción directa, se puede significar que, si es cierto que «la autoridad no puede pugnar enteramente con la razón»,

Studi sul processo civile, V, Padova, Cedam, 1947), que se recoge asimismo en la edición utilizada de la contribución de Lopez de Oñate, señala que compete a la ciencia jurídica contribuir a aumentar la certeza del derecho, es decir, «a rendere sempre più intelligibile la portata delle regole prestabilite dal legislatore all'agire umano ed a mettere il singolo in condizione di calcolare in anticipo, con previsioni sempre più sicure, le conseguenze giuridiche delle proprie azioni» (pág. 174). Por su parte, en el comentario crítico que dedica a la obra de LóPez de OÑate, CARnelutti, La certezza del diritto, en Rivista di diritto civile, XX, 1943, págs. 81 ss. (luego vuelto a publicar en Discorsi intorno al diritto, II, Padova, Cedam, 1953), que se recoge asimismo en la edición utilizada de la contribución de Lopez de Oñate, subraya asimismo la gran ventaja de la certeza, que se cifra - diceen poder prever (los particulares) las consecuencia jurídicas de su conducta (pág. 193), expresando eficazmente que «la certezza del diritto giova e l'incertezza nuoce l'attività degli uomini; a questi per agire occorre sapere ciò che debbono o non debbono fare e perciò a quali conseguenze si spongono facendo o non facendo» (pág. 200).

En el muy elogioso y profundo comentario que se contiene en la edición utilizada de la obra de LóPEZ DE OÑate, CAPOGRassi, Considerazioni conclusive (anteriormente publicado en Opere, V, Milano, Giuffrè, 1959), sobre afirmar que «la certezza... sta alla radice di tutto il mondo del diritto» (pág. 245), señala que, gracias a la certeza, «il soggetto sa con perfetta sicurezza come dall'ordine che è nato da quella norma e da quella legge, il suo contegno sarà qualificato», estableciendo una relación entre certeza, legalidad y objetividad (pág. 278).

7 Cfr. Vico, La scienza nuova (9a ed.), Milano, BUR, 2004, pág. 177 s., en una -la IX- de sus conocidas «degnità», y también, por referencia a ella en pág. 656. Este filósofo había expresado también que los juicios propuestos por los hombres -se refiere a los de las épocas primeras- podían hacerse con verdad en la forma pero que frecuentemente podían resultar falsos en la materia o -como diríamos hoy- en el fondo: cfr. VICO, La scienza nuova cit., pág. 496. Este pensador intentó explicarse la evolución del género humano a partir de la consideración retrospectiva de las primitivas épocas que llama heroicas o poéticas.

${ }^{8}$ Tomo estas expresiones de su transcripción en la obra de CROCE, La filosofia di Giambattista Vico (6 $6^{\mathrm{a}}$ ed.), Bari, Laterza, 1962, pág. 101, que las refiere como contenidas, dentro de la producción «vichiana», en Opere (a cura di Ferrari) ( $2^{\mathrm{a}}$ ed.), Milano, Società Tipografica de' Classici Italiani, 1852-1854, III, pág. 53. Véanse contenidas las mismas iniciales ideas en VICO, La scienza nuova cit., pág. 178, «degnità» X. 
porque, en su caso, las leyes «no son leyes sino monstruos de leyes», también lo es que, si lo que afirman las normas es «cierto por autoridad», puede perfectamente suceder que lo que digan las leyes no se asiente en la verdad, ya que ésta no depende de lo que se diga con autoridad puesto que la «verdad es -o, lo que es lo mismo, se aprecia-por la razón» ${ }^{9}$.

Sobre la inicial base de estas por lo demás bastante sencillas indicaciones, debemos tener en cuenta que el derecho, tratando de propiciar la conservación de la sociedad y, por tanto, una convivencia ordenada y en el mayor grado posible pacífica, busca fundamentalmente proporcionar a los consociados, en el aspecto objetivo, seguridad jurídica o estable y precisa fijeza del régimen que determina el alcance de las situaciones que les afectan y, en el aspecto subjetivo, certeza sobre la juridicidad ${ }^{10}$, ya que sin la implantación de ambas no podría alcanzarse el mejoramiento o perfeccionamiento social que da lugar al valor de la justicia, proclamado como superior por el art. 1.1 de nuestra Constitución ${ }^{11}$. En relación a estas mismas indicaciones hemos de considerar también, como ha puesto magistralmente de relieve, en su magnífica obra de teoría general del derecho, el procesalista español Jaime Guasp, que tal seguridad se coordina complementariamente con la certeza que asimismo deriva del ordenamiento y en función de las cuales los ciudadanos se conducen y se deciden respecto de sus actividades ${ }^{12}$.

${ }^{9}$ El planteamiento básico que encierra tal afirmación se reporta a la célebre frase hobbesiana de que auctoritas non veritas facit legem: cfr. HobBES, Leviathan, sive de materia, forma et potestate civitatis ecclesiastiche et civilis, de 1651, en Thomas Hobbes opera filosofica (al cuidado de Molesworth), III, Londini, 1841, reimpresión Scientia Verlag Aalen, Darmstad, 1966, pág. 202, con la que enlaza la tradición voluntarista que inspira habitualmente las concepciones doctrinarias modernas del derecho.

${ }^{10}$ La relación entre los conceptos indicados en el texto constituye el aspecto básico sobre el que se desenvuelve el contenido del ya indicado volumen de LAPORTA, RUIZ Manero y Rodilla, Certeza y predecibilidad de las relaciones jurídicas.

En el contexto en que se sitúan las calificaciones alternativas utilizadas en el texto, las mismas no se contradicen y se corresponden con las de ser la verdad objetiva y la certeza, en el sentido de certidumbre, subjetiva.

${ }^{11}$ Como ha explicado el Tribunal Constitucional, en su STC 27/1981, de 20 de julio (ponente Fernández Viagas), la seguridad se compenetra sin formar compartimentos estancos con los demás principios a que también se refiere el art. 9.3 Const., de manera que «la seguridad jurídica es la suma de estos principios, equilibrada de tal suerte que permite promover, en el orden jurídico, la justicia y la igualdad, en libertad».

12 Esta necesaria relación de equilibrada complementariedad entre la seguridad y la certeza jurídicas ha sido brillantemente indicada en la muy coherente y escasamente citada -desde luego, no en los ya numerosos manuales existentes en relación a la homónima nueva asignatura del actual «grado» universitario en derecho- obra de teoría general del derecho debida a GuAsp, Derecho, Madrid, 1971, págs. 315 a 317.

En relación a dicha complementariedad expresa agudamente este autor (pág. 318) que «un mundo jurídico simplemente seguro dejaría la duda de si se trataba de un mundo fun- 
Lo que ocurre es que, ya a partir de estas primeras y breves referencias doctrinales, no puede dejar de apreciarse que, según es constatable, lo que el derecho dice y afirma como cierto, en función de su autoridad, no siempre se corresponde con la verdad, que se percibe o se descubre por la razón, de manera que, si bien en la mayoría de los casos el ordenamiento dispensa seguridad a través de la certeza que se deriva de la realidad de una manera directa y natural, no faltan ocasiones en que las leyes, debiendo proporcionar certeza para cumplir-publice interest-su función de organización de la vida social, han de recurrir, de manera indirecta y artificial, a provocar ellas mismas, creando esa particular realidad jurídica que es fruto de la dimensión constitutiva del derecho, la certeza que procura certidumbre y seguridad a los ciudadanos ${ }^{13}$. En función de este particular modo de operar del ordenamiento, se puede entender, por ejemplo, que una cosa sea considerada indivisible por el derecho porque «esencialmente» lo es en la realidad, pero que también se la pueda tener por indivisible porque así lo ha decidido la ley,

dado jurídicamente sólo en apariencia: mundo ilusorio, en el que los sujetos del derecho, sugestionados acaso por técnicas meramente propagandistas, soñarían que tendrían la tranquilidad social que realmente les estaría sustraída. Y un mundo jurídico simplemente cierto, sin seguridad subjetiva, se hallaría probablemente en el mismo trance de incertidumbre histórica que si estuviera realmente desequilibrado, pues los habitantes de ese mundo vivirían como si su paz externa no existiera, al margen de un reposo que carecería de virtud aquietadora por su misma alienidad subjetiva». «Las razones de preferir la seguridad a la certeza o a la inversa -concluye-, son, en sí, tan recíprocamente irreductibles que no cabe otorgar la primacía a ninguno de estos dos aspectos de la paz, en contraste con el otro, por motivaciones absolutas: pero, a salvo esa preferencia variable, la exigencia básica de la paz forzosamente ha de estar integrada, en la dosis que cada uno formule, por un ingrediente de paz subjetiva, que es la seguridad humana en el derecho, y por un ingrediente de paz objetiva, que es la certeza impersonal que a ese mismo derecho cabe atribuir».

El sentido objetivo de la seguridad jurídica y el subjetivo de la certeza del derecho son también subrayados por PÉREz LuÑo, La seguridad jurídica, Barcelona, Ariel, 1991, págs. $21 \mathrm{~s}$. y $106 \mathrm{~s}$.

13 Un destacado filósofo del derecho ha significado a este respecto la idea de que «el derecho no es otra cosa sino una serie de operaciones interpretativas llevada a cabo sobre las cosas y los estados de las cosas de la realidad», señalando, en definitiva, que «nuestra tesis central puede enunciarse como sigue: el derecho es una interpretación autoritativa de la realidad, que atribuye a sus elementos estatutos o propiedades (cursivas del autor)» y concluyendo que «el derecho es una hermenéutica oficial del mundo»: cfr. GRZEGORCZYK, Le droit comme enterprétation oficielle de la realié, en «Droits», 1990, $\mathrm{n}^{\circ}$ 11, págs. 31 ss.

En la perspectiva ideológica del denominado constructivismo radical, un planteamiento extremoso sobre el desdoblamiento de la «realidad material» y la «realidad jurídica», en el básico sentido informador de que «la verdad no se descubre, se confecciona» y de que «la verdad se genera y se gestiona desde dentro de un sistema teórico», se encuentra en Martínez García, La imaginación jurídica, Madrid, Dykinson, 1999, esp. pág. 10. 
como es el caso de la llamada unidad mínima de cultivo, de la parcela mínima urbanística o de la extensión mínima de explotación forestal, y que asimismo se afirme legalmente que es indivisible la cosa que dividida resultaría inservible para el uso a que se destina o, incluso, la cosa que desmerecería mucho por su división ${ }^{14}$. Por otra parte, esa misma dimensión constitutiva mediante la cual tiende el derecho a organizar la vida social determina que una cosa es inmueble porque lo es «por naturaleza», pero también que se consideran inmuebles, porque así se considera que conviene, los tractores o los sacos de abono destinados a la explotación de una heredad ${ }^{15}$.

Ello puede ser así, en definitiva, porque, mientras que «la verdad es» por si misma, «la certeza se asevera» y porque la aserción de la certeza lo mismo puede proceder de una contemplación o de una verificación de la realidad que es res quidem vera ${ }^{16}$ - que agotarse - pro certo o pro veritate habetur-en una mera, aunque eventualmente justificada, declaración ${ }^{17}$.

\subsection{Las certezas públicas de las verdades oficiales.}

Aunque pueda decirse, según una apreciación doctrinal muy extendida ${ }^{18}$, que, a diferencia de los enunciados sobre hechos que pueden ser verdaderos

${ }^{14}$ Cfr., entre otros, arts. 401.1, 404 y 1062.1 Cc. y art. 24 de la Ley 19/1995, de 4 de julio, de modernización de explotaciones agrarias.

${ }^{15}$ Cfr. art. $334,1^{\circ}, 5^{\circ}$ y $7^{\circ} \mathrm{Cc}$.

16 Por eso la frase latina veritatem imitare significa «reproducir la realidad».

${ }^{17}$ La relación entre certeza y verdad, que aquí se propone en una perspectiva preferentemente pragmática, que tiene particularmente en cuenta aspectos fenomenológicos y aplicativos de la dinámica jurídica en la vida social, puede examinarse en la dimensión, de carácter general, de la dogmática y de la teoría jurídicas, desde muy diversos puntos de vista: véase, por ejemplo, Diciotтi, Verità e certezza nell'interpretazione della legge, Torino, Giappichelli, 1999, o también, en una dimensión valorativa de la escisión entre verdad y certeza, Nicolini, Verità e certezza del diritto, en Iustitia, 1949, págs. 41 s., quien sostiene que, en caso de incompatibilidad entre justicia (verdad) y certeza, debería darse preferencia a esta última, aunque reconoce que, en la compleja situación propia de la actual sociedad democrática, no puede esperarse que se «consienta al juez apreciar la bondad de la norma estatal en la piedra de toque de las normas naturales y quedar ligado únicamente a la vera lex, a la lex iusta», de manera que, desde el punto de vista del jurista que es a la vez católico y demócrata, concluye que «estamos obligados a contentarnos con considerar al juez ligado a la ley que presuminos justa, por haber sido querida por todos, o por los más». «Seguir en vano un sumo bien, una gran meta, cerrando los ojos al frecuente mal que a cada paso dejaremos aparecer en nuestro camino... querría decir - concluye- poner en serio peligro libertad e igualdad, conquistas tan caras a nosotros, como juristas y como católicos»».

18 Es bien conocida, por lo demás, la afirmación de Kelsen de que «no se puede hablar de una «verdad» del derecho. En efecto, el derecho (incluso el derecho justo) es norma y como tal no puede ser verdadero ni falso»: cfr. KELSEN, Teoria generale delle norme (trad. it. de Torre), Torino, Einaudi, 1985, pág. 281. 
o falsos -apofánticos», según la terminología de los expertos- las reglas del derecho no son, en cuanto proposiciones normativas que expresan discursos directivos, ni verdaderas ni falsas ${ }^{19}$, «la ley hace saber a cada uno lo que puede querer», de modo que «precisamente en ello se realiza el beneficio que se hace posible con su certeza $»^{20}$. De este modo las normas proporcionan las

Se trata de una apreciación acaso no compartida siempre entre las gentes corrientes, según hace notar -si bien es secuaz de los planteamiento voluntaristas de que se hace mención en el texto- KaLINOWSKI, Le problème de la verité en morale et en droit, Lyon, Vitte, 1967, pág. 62 s. También ente los filósofos juristas y los teóricos del derecho se discute a veces la procedencia de la radical afirmación recogida en el texto, de modo, por ejemplo, que algunos sostienen que una norma es verdadera si es válida, si es observada, si se corresponde con la moral, si es justa, si refleja la racionalidad del consenso o también si se adecua a la Verdad originaria o de principio.

Una interesante reflexión sobre las cuestiones suscitadas en el texto se encuentra en Opocher, Il diritto senza verità, en Studi giuridici in onore di Francesco Carnelutti, I, Padova, Cedam, 1950, págs. 177 ss., que relaciona la verdad del derecho con la justicia y la legalidad (pág. 183), una verdad que no puede entenderse como concepto puramente formal (págs. 185 s.), sino como manifestación de la concreta moralidad de la acción (págs. 188 ss.). Este autor insiste en las mismas ideas en Opocher, Lezioni di filosofia del

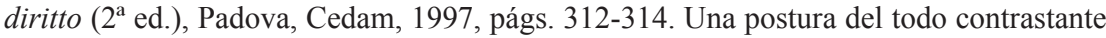
puede observarse en SCARPELLI, L'etica senza verità, Bologna, 1980.

19 Así, por ejemplo, GUASTINI, Interprétation et description des normes, en Interprétation et droit (dir. AMSELEK), Bruxelles, Bruyland, 1995. pág. 90, señala que, a diferencia de los enunciados descriptivos, que se refieren a hechos y «que, por esta misma razón, pueden ser verdaderos o falsos, pudiendo ser controlados por medios empíricos», «los enunciados normativos no pueden ser ni verdaderos ni falsos», extendiéndose luego (págs. 97 s.) en la justificación de tal afirmación; y, por su parte, PATTARO, Interprétation, systématisation et scienze juridique, en Interprétation et droit cit., pág. 108, también expresa que, «como todas las prescripciones, las leyes no son ni verdaderas ni falsas y en ello está la razón por la cual la solución de las controversias jurídicas se confia a los tribunales».

Sobre la afirmación contenida en el texto, recurrente en las exposiciones sobre la denominada «teoría del derecho», puede verse ahora el interesante libro de PINTORE, $I l$ diritto senza verità, Torino, Giappichelli, 1996, del que hay trad. esp. bajo el título de El derecho sin verdad, a cargo de Garrido Gómez y Del Hierro, Madrid, Dykinson, 2005. En esta destacable contribución, la autora, profesora de filosofía del derecho que se coloca en la línea de la que se ha dado en llamar teoría analítica, examina la negada relación entre la verdad y las reglas jurídicas en cuanto expresión de un discurso directivo o normativo, en las posibles perspectivas en que dicha eventual relación podría intentar ser explicada, en cuanto a entender tal relación como correspondencia (del derecho con la verdad natural, con la verdad común o con la verdad de las cosas), como coherencia (sistematicidad del conjunto normativo o racionalidad y corrección del mismo), como corrección procedimental de las soluciones jurídicas o como, en fin, consenso sobre la disciplina normativa, perspectiva esta última que en su caso se preferiría en una apreciación valorativa de las normas propia de una sociedad democrática.

${ }^{20}$ Cfr. López de OÑate, La certezza del diritto cit., pág. 50. 
vías a través de las cuales -y en razón de la seguridad derivada de la certeza que aquéllas proponen- pueden transitar útilmente los particulares. En este sentido, y de una parte, la observancia de las reglas establecidas como portadoras de certeza otorga validez y eficacia a los actos de los ciudadanos y su inobservancia determina para ellos una sanción desfavorable y, de otra, la misma finalidad de orientación jurídica que de las normas deriva suministra certezas sobre los otros consociados, sobre la trascendencia de sus actos o sobre los derechos que les corresponden y las situaciones que les afectan o señala los medios de averiguación determinativa de tales derechos y situaciones en caso de controversia ${ }^{21}$.

Con estas últimas finalidades apuntadas ${ }^{22}$, que germinan en el seno del iluminismo como respuesta a la exigencia de racionalidad jurídi-

${ }^{21}$ En el sentido indicado en el texto, los juristas franceses hablan cabalmente, en ocasiones, de «besoin de prévisibilité», al que sin duda socorre, procurando la colocación de las normas jurídicas en un sistema inteligible y riguroso, su adecuada interpretación: cfr. Chevalier, Les interprétes du droit, en Interprétation et droit cit., pág. 126. De «besoin de certitude et sécurité», en el sentido de satisfacerse tal necesidad de los ciudadanos con la estabilidad de las normas, había ya hablado RIPERT, Les forces créatrices du droit, París, L.G.D.J., 1955, pág. 88.

${ }^{22}$ Desgraciadamente, son muchas las causas de la permanente y creciente fragilidad de la seguridad jurídica, como la multiplicidad de los centros de producción normativa o «el conjunto abigarrado de agencias centrales y periféricas de producción de normas» (así, Rodilla, en Laporta, Ruiz Manero y Rodilla, Certeza y predecibilidad de las relaciones jurídicas cit., pág. 25), la superabundancia legislativa o la que puede definirse como «compulsión general hacia la creación incesante de normas jurídicas» (así, LAPORTA, ivi, pág. 63), los frecuentes cambios legislativos o la «velocidad y cambio de la legis innovatio cotidiana» (así, LAPORTA, ivi, pág. 68), la «creación normativa coyuntural» (así, Rodilla, ivi, pág. 25), la falta de claridad en algunas leyes, etc. Sobre estos problemas puede verse la interesante contribución de García De EnTERría, Justicia y seguridad jurídica en un mundo de leyes desbocadas, Madrid, Cívitas, 1999 y, en relación a la multiplicación de los centros o «feudos jurídicos», véase BERMEJO VERA, El declive de la seguridad jurídica en el ordenamiento plural, Zaragoza, Academia Aragonesa de Legislación y Jurisprudencia (Discurso de ingreso), 2005.

El indicado libro Certeza y predecibilidad de las relaciones jurídicas tiene como núcleo fundamental (págs. 55 a 93) una ponencia de Laporta, del mismo título del volumen, en la que se previene, en cuanto puede afectar a la certeza del derecho, frente a la frecuente y exagerada apelación judicial a los principios en lugar de a las reglas y, en consecuencia, al «alejamiento paulatino del par «regla-legislador» y un correlativo acercamiento paulatino al par «estándar-juez»... (lo que le) hace temer por la certidumbre y la predicibilidad de nuestro derecho futuro» (pág. 63). A ella sigue una contraponencia de RUIZ MANERo de intención superadora, del expresivo título de Las virtudes de las reglas y la necesidad de los principios (págs. 95 a 120) y a ambas se antepone una amplia y ponderada introducción de Rodilla, intitulada Imperio de la ley y principios. Presentación de un debate (Págs. 9 a 53). En la línea de la postura sostenida por el primero de los autores, vid. también Laporta, El imperio de la ley. Una visión actual, Madrid, Trotta, 2007. 
$\mathrm{ca}^{23}$, se corresponden las que por algunos se ha dado en llamar «certezas públicas $»^{24}$, que proporciona el poder ejecutivo -así las certificaciones, las escrituras noariales ${ }^{25}$, los asientos de los registros civil ${ }^{26}$, de la propiedad $^{27} \mathrm{o}$ mercantil ${ }^{28}$, las resolución administrativas, las cédulas de habitabilidad o las determinaciones municipales de uso de los inmue-

${ }^{23}$ El iluminismo como doctrina jurídica tiende, en efecto, a colocar en el centro de su reflexión a la figura del legislador, tanto por considerarlo como intérprete del derecho natural como, por lo que aquí interesa por una exigencia fundamental de certeza y de poner fin al conflicto entre las fuentes del derecho privilegiando sobre cualquier otra a las leyes generales y abstractas. Sobre el iluminismo jurídico puede verse, en general, CATTANEO, Illuminismo e Legislazione, Milano, Giuffrè, 1976.

${ }^{24}$ Cfr. Giannini, s.v. «Certezza pubblica», en Enciclopedia del diritto, VI, Milano, Giuffrè, 1960, págs. 769 a 792.

${ }^{25}$ Véase, por ejemplo, Bolás Alfonso, La documentación pública como factor de certeza y protección de los derechos subjetivos en el tráfico mercantil, en La seguridad jurídica y el tráfico mercantil (coord. Bolás Alfonso), Madrid, Cívitas, 1993, págs. 41-70.

Sin embargo, como advierten, entre otras muchas las STS. de 8 y 16 de mayo de 1973 , de 8 de mayo de 1980, de 15 de febrero de 1982, de 14 de febrero, de 14 de marzo, de 15 de mayo y de 2 de junio de 1983, de 10 de julio y de 5 de diciembre de 1984, de 24 de febrero de 1986 y de 5 de noviembre de 1988, «la eficacia en materia de contratos otorgados ante notario no alcanza a la verdad intrínseca de las declaraciones de los contratantes»..., «dado que el documento público da fe del hecho y de la fecha, es decir lo comprendido en la unidad de acto, pero no de su verdad intrínseca» se distingue aquí, según es fácil de apreciar entre una «verdad extrínseca o formal»-que es la que, en principio, vale- y una «verdad intrínseca o real».

${ }^{26}$ Dispone la ley del registro civil de 8 de junio de 1957 que el contenido de los asientos registrales tiene valor probatorio de los hechos inscritos (art. 2), que no se pueden impugnar sin que a la vez se inste la rectificación del asiento correspondiente (art. 3); y la ley $20 / 2011$, de 21 de julio, que la ha de sustituir, determina la presunción de exactitud del contenido de los asientos registrales, en el sentido de que los hechos existentes y los actos (que figuran en los asientos) son válidos y exactos (art. 16.3).

${ }^{27} \mathrm{El}$ art. 38.1 de la ley hipotecaria, cuyo texto refundido aprobó el Decreto de 8 de febrero de 1996, establece que «a todos los efectos legales se presume que los derechos reales inscritos en el registro existen y pertenecen a su titular en la forma determinada por el asiento respectivo». El ejercicio de una acción contradictoria exige -consecuentemente- que de manera previa o a la vez se entable demanda de nulidad o cancelación de la inscripción correspondiente (art. 32.2).

En relación a la posible inexactitud de lo que manifiestan los asientos registrales, se distingue a menudo por la jurisprudencia entre realidad registral y realidad jurídica extrarregistral: cfr., por ejemplo. STS. de 10 de julio de 1984.

${ }_{28}$ El art. 7.1 del Reglamento del registro mercantil, aprobado por Real Decreto 1784/1996, de 19 de julio, dispone que «el contenido del registro se presume exacto y válido» y que sus asientos «producirán sus efectos mientras no se inscriba la declaración judicial de su inexactitud o nulidad». 
bles $^{29}$-, que proclama el poder legislativo -así la determinación de las posiciones jurídicas de los ciudadanos con la consiguiente atribución de acciones en defensa de sus derechos- o que provoca con su actuación el poder judicial. Se ha llegado incluso a decir que algunas de dichas actividades públicas no son sino expresiones del hecho de que, "por siglos, los operadores jurídicos se han encontrado como fascinados por lo que podría llamarse el «mito de la verdad» y han creído que el uso adecuado de determinados instrumentos materiales y jurídicos podría proporcionar representaciones exactas de la verdad, tanto de la verdad histórica como de la verdad científica $»^{30}$.

\subsection{Consistencia y variedad de las verdades oficiales.}

Es cierto que la perfecta coincidencia con la realidad de las aludidas certezas o representaciones oficiales de la verdad se resiente o se encuen-

${ }^{29}$ Sobre la actividad administrativa que proporciona certeza, vid. el interesante estudio de Romano Tassone, Amministrazione pubblica e produzione di «certezza»: problemi attuali e spunti ricostruttivi, en A.A.V.V., I sistemi di certificazione tra qualità e certezza (coord. CARLESI) («Collezione giuridica d'impresa», a cura di Fracchia e Occhiena), Milano, Egea, 2009, págs. 23 a 37. El autor califica a la certeza que deriva de la actividad administrativa -asientos del registro civil, registro de patentes y marcas, datos catastrales, etc.- de certeza «noticial», distinta de la certeza derivada de la ley o certeza «legal».

Sobre estas cuestiones, se recuerdan, en particular, AGUADO I CudOLÀ, La presunción de certeza en el dereco administrativo sancionador, Madrid, Cívitas, 1994, contribución a la que precede La «presumptio» de certesa com a prova de les infraccions administratives, Barcelona, Generalitat de Catalunya -Escola d'Administració Pública de Catalunya, 1992; y Durantez SAEz, «La doctrina de las presunciones y la presunción de certeza de las actas de inspección de trabajo», Cívitas. Revista Española de Derecho del Trabajo, nº 45 (enero-febrero 1991), págs. 85-102.

${ }^{30}$ Cfr. Giannini, s.v. «Certezza pubblica» cit págs. 769 s.

La temática del valor de la verdad en el derecho se refiere a una cuestión fundamental que es transversal en la reflexión de los juristas y que influye en las diversas concepciones doctrinales que éstos han formulado, desde las iusnaturalistas, que tienen en cuenta principios que constituyen los prima vera, hasta las positivistas en que se asume en abstracto como verdad lo que por tal se decide en cada momento por la ley.

En un aspecto más concreto, que, pese a su mayor delimitación no es posible considerar, más allá de alguna alusiones marginales, en esta sencilla exposición, la temática indicada ha tenido una significativa expresión en relación a la actuación de los tribunales y a la normativa que a ella conviene, a propósito de cuya evolución se han hipotizado básicamente dos modelos diferentes: el del tradicional ordo judiciarius, entendido como ordo quaestionum y ordo probationum y desenvuelto dialógicamente -mediante el contradictorio que supone el ars opponendi et respondendi- en clave dialéctica, retórica y moral y de manera argumentativa y justificativa, en el que el judicium a declarar por el juez, garante del procedimiento, vendría a proponerse como una «verdad probable», seleccionada entre las dos opuestas tesis defendidas por los litigantes (fecisti/non feci); y el del processus, de influencia iluminista, en el que, en base a criterios racio- 
tra mediatizada frecuentemente por los propios mecanismos internos que se desenvuelven dinámicamente en la vida social y que necesariamente se reflejan en la configuración de la realidad jurídica.

Piénsese, en cuanto al primero de los aspectos de la formulación de las denominadas «certezas públicas» a que se acaba de hacer referencia, que el registro civil puede manifestar que están casados quienes han simulado, según no es infrecuente, la celebración de una boda como expresión del llamado matrimonio de complacencia o que un sujeto es hijo de quien ha llevado a cabo un mero reconocimiento de los igualmente conocidos con la misma denominación; que el contenido de la escritura notarial puede ser la expresión de una venta de alcance solamente fiduciario y hecha en garantía de un acreedor que aparece como comprador; o bien que lo que dice el registro de la propiedad no se ajusta a la realidad, según ponen de relieve los abundantes supuestos de aplicación por los tribunales del art. 34 de la ley hipotecaria.

Por otra parte, las leyes recurren en no pocos casos a ficciones, como la de considerar decisión positiva o negativa de la Administración al llamado silencio administrativo, y a presunciones, como la que atribuye la paternidad del hijo al marido de la madre por consecuencia de cuanto dispuesto en el art. 116 del Código civil.

En cuanto al proceso, cuya finalidad se ordena - pro re certa- a la apreciación reconstructiva, plausible y razonable de unos hechos verificados mediante la pertinente prueba y a tomar en consideración, en función de dicha apreciación o discretio veritatis y de la calificación jurídica que convenga a tales hechos, una «verdad» sobre la que decidir aplicando las normas ${ }^{31}$, puede perfectamente ocurrir que cuanto decide el

nalistas propios de la lógica que se propone a partir del siglo XVII, se confía al juez, que viene a asumir una función burocrática, la búsqueda y el descubrimiento de una objetiva «verdad absoluta», ya lo fuera según el punto de vista de la verdad material o de la verdad formal. El primero de los modelos indicados predomina, aunque muy mediatizado por la influencia del otro, en los países latinos y del segundo fueron claros exponentes la francesa «Ordonnance civile touchant la réforme de la justice» de 1667 -conocida como «Code Louis»- y la prusiana «Justizereform» y el «Prozess-Ordung» de 1781: cfr., sobre estas alternas orientaciones, el preciso estudio de PICARDI, Les racins historiques et logiques du code de procedure civil, en L'educazione giuridica (a cura di Giuliani e Picardi), vol. V, Modelli di legislatore e scienza della legislazione, t. 1, Filosofía e scienza della legislazione, Napoli, Esi, 1988, págs. 241 a 255. Uno y otro sistema procesal han sido autorizadamente caracterizados por Giuliani, Ordine «isotomico» ed ordine "assimetrico». «Nuova retorica» e teoria del processo, en Sociologia del diritto, 1986, fasc. 2-3, págs. 81 ss.

${ }^{31}$ Cfr. Zorrilla Ruíz, «Convergencia de la justicia material y la verdad histórica en el resultado de la prueba civil», en A.A.V.V., La prueba judicial (dir. Abel Lluch, Picò I JunOY y Richard GonzÁLEZ), Madrid, La Ley, 2010, págs. 71 a 101. Aprovecho aquí ideas y expresiones tomadas de TARUFFO, Simplemente la verdad. El juez y la constatación de los hechos (trad. esp. de Accatino Scagliotti), Madrid, Marcial Pons, 2010, págs. 22 y 24, 
juez, que, en la tradición de la regla ulpianea de que res judicata pro veritate habetur ${ }^{32}$ y como «verdad judicial» ${ }^{33}$, está adornado -si su sentencia

que también se refiere, recordando el brocardo de que probatio est quaedam ratiotinatio, a constituir los medios de prueba instrumentos racionales dirigidos al descubrimiento de la verdad (pág. 38).

Sobre la búsqueda de la verdad en el proceso a través de la prueba puede verse también CApograssi, Giudizio processo scienza verità, en Opere, vol. V, Milano, Giuffrè, 1959, págs. 51 a 76, y del mismo filósofo del derecho y autor, exaltando la importante labor judicial -en cuanto que «accerta la verità» y su alto menester consiente «ritrovare la verità, accertare la verità, ridare la verità alla vita»-Pensieri a Giulia, Milano, Bompiani, 2007, «pensieri» 1920 y 1929, págs. 1886 s. y 1892.

En el pensamiento de Opocher, Lezioni di filosofia del diritto cit., pág. 311, también se aprecia que «la justicia como reconocimiento de la verdad aparece del todo predominante en el plano del proceso y, por tanto, en el juicio del juez».

32 Cfr. Digesta, 50, 17, 207.

${ }^{33}$ Un procesalista eminente como CARnelutti, La prova civile, Roma, Athenaeum, 1915 , págs. $31 \mathrm{~s}$. indica, mediante las palabras que siguen y por referencia a la actividad judicial, la distinción entre verdad formal y verdad material: «el resultado de la investigación jurídicamente limitada o disciplinada no es ya la verdad material o, como se diría con una eficaz perogrullada, la verdad verdadera, sino una verdad convencional, que se bautiza como verdad formal, en cuanto que a ella conduce una averiguación regulada en sus formas, o como verdad jurídica, en cuanto la misma se busca mediante leyes jurídicas, no sólo mediante leyes lógicas, de manera que únicamente por efecto de estas leyes jurídicas sustituye a la verdad material».

Sobre los aspectos relacionados con la prueba de la «verdad judicial» puede verse la contribución de González De Audicana Zorraquino, la verdad judicial como complemento de la convicción del juzgador en los procesos civiles dispositivos, en A.A.V.V., La prueba judicial cit., págs. 247 a 268. Véase también, en relación a estos aspectos, la contribución de Gascón Abellán, Los hechos en el derecho. Bases argumentales de la prueba, Madrid, Marcial Pons, 1999 (hay 2a ed. de 2004 y 3a ed. de 2010). En relación a la percepción judicial de la verdad de los hechos sobre la base valorativa de criterios jurídicos, véase también TARUfFo, La prueba de los hechos (trad. esp. de Ferrer Beltrán), Madrid, Trotta, 2002, esp. págs. 39 ss., 91 ss. y 128 ss., de cuyo autor se han publicado en España, más recientemente, la monografía TARUfFo, La prueba (trad. esp. de Márquez), Madrid, Marcial Pons, 2008, una contribución contenida en TARUfFo, ANDRÉs IBÁÑEz y CANDAU PÉrez, Consideraciones sobre la prueba judicial, Madrid, Fundación Coloquio Jurídico Europeo, 2009 y, en 2010, la ya citada monografía Simplemente la verdad. Ha de tenerse en cuenta, en todo caso, que los hechos no son nunca vistos directamente por el juez, sino que éste los percibe a través de los medios de prueba, mediante una determinación de tales hechos por la apreciación valorativa de las pruebas practicadas. En la labor judicial de aproximación reconstructiva de los hechos la labor del juez se asemeja, en cierto modo, a la del artista, que más que mirar escruta las cosas para trasladarlas al lienzo, en una función casi adivinatoria: vid., sobre estos aspectos, Silva Alonso, La función del juez en la vida del derecho, Asunción, 1970, págs. $31 \mathrm{~s}$.

Es de señalar, de todas formas, que -en particular, gracias a la transcendencia real del principio de audiencia propio del proceso contradictorio- se alcanzará con frecuencia 
ya es firme- de «certeza», no se corresponda con la «verdad objetiva», pero que, aún sin «ser verdadero», deba «ser tenido por verdadero o ser aceptado como verdadero» ${ }^{34}$. Se trataría, en suma, de un «subrogado de la verdad $»^{35}$ o de una «verdad suficiente» a los fines de la aplicación de la norma jurídica, verdad únicamente verificable en el ámbito del discurso propio del proceso $^{36}$ y que, cuando la sentencia que la determina devie-

una conclusión judicial que aprecie la veracidad de los hechos, de modo que, en tal caso, la decisión del juzgador no dará lugar a la existencia diferenciada de una verdad formal y una verdad material: vid., a este propósito, SANCHO GARGallo, «Juris prudentia» del juez civil (discurso de ingreso, como académico numerario, en la Acadèmia de Jurisprudència i Legislació de Catalunya), Barcelona, 2010, esp. págs. 29 a 32. La contestación al discurso, a cargo de Mullerat, contiene apreciaciones, también de derecho anglosajón, respecto del asunto que aquí interesa en págs. $62 \mathrm{~s}$.

${ }^{34}$ Utilizo aquí expresiones de Ferrer Beltrán, Prueba y verdad en el derecho (2a ed.), Madrid, Marcial Pons, 2005. De la relatividad de la verdad derivada de la prueba practicada en el proceso se hace referencia también en Ferrer Beltran, La valoración racional de la prueba, Madrid, Marcial Pons, 2007, pág. 20. Véase también BuENO ОсноA, Proceso a la prueba y la verdad, en A.A.V.V., La prueba judicial cit., págs. 103 a 122, que en la pág. 116 recoge asimismo las expresiones de Ferrer Beltrán reportadas en el texto.

Una aguda reflexión sobre la relación de la justicia con la realidad, la verdad y la seguridad jurídica es ofrecida por Pérez DuARTE, «Prueba, hecho y verdad: el impresionismo en el derecho», en A.A.V.V., La prueba judicial cit., págs. 139 a 162.

35 Tomo esta eficaz expresión de CARnelutti, La certezza del diritto cit., pág. 198, que también señala que «la exigencia de la certeza asume, en el proceso, un relieve precisamente plástico en la fórmula de cosa juzgada» (pág. 198). Por su parte, CAPOGRASSI, Considerazioni conclusive cit. insiste en que el pro veritate habetur de la cosa juzgada «puede no ser la verdad»: «già nella esitenza stessa della cosa giudicata-concluye- è un prescindere, in certo modo e a un certo punto, della verità» (pág. 247).

${ }^{36}$ Señala TARUfFo, Simplemente la verdad cit., pág. 82, que, en el contexto del discurso del proceso, es necesario asumir «un concepto específico de verdad, según el cual un enunciado que describe un hecho puede ser reconocido como verdadero si ha sido racionalmente confirmado por las pruebas presentadas en el proceso».

Hace pensar a este respecto la siguiente reflexión de Corradini H. Broussard, Nottario. Novanta pensieri sull'etica e il diritto e l'economia, en Diritto Privato. Studi in onore di Antonio Palazzo, 1 (a cura di Donati e Sassi), Torino, Utet, 2009, pág. 255-285, esp. pág. 280 (pensiero 76). Escribe el profesor pisano: «Per il giudice la verità è nelle carte del processo. Facta sunt servanda. E lui observa solo i fatti che sono in queste carte.- Quod non est in actis, non est de hoc mundo: una foglia di fico per coprire nudità.- Dagli atti i fatti. Anche da una testimonianza falsa, di cui in atti non si è scoperta la falsità.- Segno che la verità processuale non coincide con la verità ontica.- È ingenuo sostenere che alla verità si giunge nel processo, che il processo è il luogo in cui la verità si esalta al suo splendore, il luogo in cui il diritto si fa verità ed è verità.- Come dire che esistono mezze-verità, dimenticando che la verità o è intera o non è verità e che non è verità la verosimiglianza». 
ne firme, adquiere, en aras de la seguridad jurídica y como conveniente aceptación del «mal menor» ${ }^{37}$, la eficacia de la «certeza» o de «hacer creer verdadero» lo que acaso no es tal en la realidad ${ }^{38}$. Se da lugar así a una «convencionalidad de la verdad» de las decisiones judiciales ${ }^{39}$, de modo que, por eso, puede decirse, en conclusión, que lo definitivamente juzgado «es verdad, pero (que) aunque no lo fuera produce los mismos efectos que si lo fuera», de modo que, «tanto si es verdad como si no lo es, es como si fuera verdad» ${ }^{40}$. De aquí que a la decisión del juez se

37 La STS. de 30 de diciembre de 2010, que recoge doctrina y pasajes de la de 20 de abril de 2010, expresa que «la inmutabilidad de la cosa juzgada está en el principio de seguridad jurídica, pues la vida jurídica no puede soportar una renovación continua del proceso. El ordenamiento jurídico prefiere el efecto preclusivo de la cosa juzgada como mal menor ante el principio de seguridad jurídica», de modo que por ello -concluye- «la cosa juzgada imposibilita replantear indefinidamente un problema ante los tribunales de justicia».

${ }^{38}$ Cfr. Bettetini, Verità, giustizia, certezza: sulla cosa giudicata nel diritto della Chiesa, Padova, Cedam, 2002, pág. 11, que señala que tal eficacia «es bien lejana del favor veritatis ínsito en el ordenamiento de la Iglesia, en el que más allá de y sobre la autoridad de la cosa juzgada, se coloca la eficacia de la verdad, sustituyéndose a una razón política de lo juzgado una razón de moralidad: el ius constitucionis se aparta para dar lugar... al ius veritatis».

En un contexto distinto a la dimensión pragmática en que se encuadra esta sencilla exposición, la referencia a una certeza objetiva del derecho encarnada en el derecho natural ha sido tradicional entre los iusnaturalistas: véase, a este propósito, LENER, La certezza del diritto, il diritto naturale e il magistero della Chiesa, en Studi giuridici in onore di Francesco Carnelutti, I, cit., págs. 345 ss.

39 Tomo la expresión de Jori, Il formalismo giuridico, Milano, Giuffrè, 1980, pág. 52.

40 Las situaciones reales que pueden inferirse de cuanto significado en el texto plantean el problema de si el logro de la certeza no se consigue a costa de la justicia, sobre cuya cuestión ha hecho interesantes indicaciones - muy brillantes, como suyas- CARnelutti, La certezza del diritto cit., que se plantea si no es «posible que certeza y justicia, lógicamente inseparables, no tanto estén separadas cuanto sean inconciliables la una con la otra» (pág. 201) y «no acaben tanto por disociarse cuanto por estar en las antípodas la una de la otra» (pág. 203), como en el caso al que alude de la cosa juzgada en el supuesto de que la sentencia firme que el juez pronuncia sea injusta (pág. 204). Sin embargo, aunque no se puede negar que pueda ocurrir que en el caso concreto la certeza se escinda de la justicia, hay que considerar, como expresa CApograssi, Considerazione conclusive cit., págs. 246 s., que se refiere, además de al caso de la cosa juzgada a la institución de la prescripción, que «la certezza, il conseguimento della certezza, è essa stessa giustizia, parte della giustizia», lo que en definitiva puede justificarse con la idea de la consecución, aunque sea a base de sacrificar algunos intereses, de la paz social. Téngase en cuenta, por lo demás, que, si en algunos momentos ha parecido que podían presentarse como contrapuestas justicias y seguridad y obtenerse la segunda a costa de la primera, hoy se considera por muchos que ambas se integran entre sí como también ha declarado nuestro Tribunal 
le denomine «veredicto», palabra que procede de una latinización ${ }^{41}$ que significa «dicho verdadero».

Es en razón de todo ello por lo que en el derecho encontramos certezas que se constituyen sobre verdades que efectivamente lo son pero también, necesariamente, certezas que se asientan, al no poderse amparar en verdades que se corresponden indudablemente con la realidad, sobre verdades que únicamente lo son en cuanto verdades presuntas, verdades presupuestas, verdades aparentes, verdades simuladas, verdades fiduciarias, verdades fingidas o incluso verdades eventual o seguramente falsas, pero que para el derecho podemos también decir que dan lugar a «certezas públicas» basadas en «verdades oficiales». En todos estos casos se asiste a supuestos que el derecho acoge como «ciertos», por razones pragmáticas de utilidad o de conveniencia -de política legislativa, se podría decir más técnicamente-, y que acaso no son ciertos o que son seguramente inciertos, pero que son formalmente constituidos como «verdades putativas» y, como tales, «creíbles como ciertas» a los fines organizadores del ordenamiento, que las asume -siempre sobre el sustrato o denominador común de proporcionar seguridad jurídica- ya sea en función de atender a la equidad, como en el caso de las verdades aparentes ${ }^{42} \mathrm{o}$ de las verdades ficticias ${ }^{43}$, ya en función de atender a la llamada economía procesal o de favorecer la tranquilidad social y apro-

Constitucional en la ya citada STC. 27/1981, de 20 de julio, al considerar el contenido del art. 9.3 Const.

Tomo las expresiones reportadas en el texto de PinTó Ruíz, No siempre aquello que «debe ser» alcanza virtualidad ontológica, el singular supuesto del texto de Modestino (D. XLII, I, 28) y la cosa juzgada, en Estudios (de la Real Academia de Jurisprudencia y Legislación), Madrid, 2010, págs. 495, n. 8, y 500, n. 21. Se trata en esta jugosa exposición del supuesto, a que se refieren las STS. de 7 de octubre de 1898 y de 8 de marzo de 1928 , de dos decisiones contradictorias, arbitrales en el primer caso y jurisprudenciales en el segundo, de las que se pedía despacho de ejecución. Con argumentos convincentes, producto tanto de la reflexión como del sentido común, defiende brillantemente el autor la preponderancia de la primera de las decisiones dictadas, que excluye de todo valor, en razón del efecto negativo de la cosa juzgada, a la segunda.

${ }^{41}$ Del inglés «veredict» o del francés normando «veir dit»: cfr. Moliner, Diccionario de uso del español, II (j-z) (3ª ed.), Madrid, Gredos, 2007, pág. 3030.

${ }^{42} \mathrm{La}$ atención por el derecho a la apariencia como «règle d'equité» es frecuentemente recordada por la doctrina: véase, por ejemplo, el interesante libro de DanIs-FanTôME, Apparence et contrat, Paris, L.G.D.J., 2004, pág. 343.

${ }^{43}$ Que el recurso a la ficción legal está inspirado en la equidad es, desde antiguo, un lugar común entre los juristas: cfr. Cujacius, Opera, ad parisiensis fabrotianam editionem diligentisima exacta, in tomis XIII distribuita, Pars tertia, t. III, Prati, 1837, col. 1186, o también Blackstone, Commentaries on the laws of England, 1758-1763, vol. III, pág. 43, a quien se debe la afirmación de que in fictione semper subsistit equitas. Por lo demás se debe a Bartolo de Sassoferrato la célebre opinión de que omnis fictio est introducta ex quadam naturali aequitate. 
vechar para ello la inferencia que proporcionan los datos de la experiencia o la que sugiere la normalidad, como en el caso de las verdades presuntas ${ }^{44}$, ya en función de dar cauce a los intereses lícitos de los consociados, como en el caso de las verdades simuladas o de las verdades fiduciarias ${ }^{45}$, o ya en función de justificar y no sólo dictar una regla positiva o una solución jurisprudencial, como en el caso de las verdades presupuestas ${ }^{46}$.

De la manera expuesta, resulta, pues, que, si las más de las veces la norma de derecho reconoce y consagra la realidad histórica o material, otras manipula y «modifica su sentido en función de la conveniencia social» y «otras, en fin, su preocupación por la conveniencia social le decide a desconocer esta realidad hasta en su evidencia». Se puede decir, con palabras de un ilustre jurista francés, que, «en el primer caso, el derecho busca la verdad material, que, en el segundo, la deforma y que, en el tercero, la rechaza», si bien «es siempre la misma preocupación de oportunidad la que inspira su preferencia y la que dirige su actitud $\rangle^{47}$.

\subsection{La justificada asunción instrumental de las verdades oficiales.}

Estas indicaciones no nos deben sorprender, puesto que topamos en muchas ocasiones con supuestos de la realidad práctica que nos rodea que las avalan, y puesto que, como juristas, somos bien conscientes de que a tales supuestos, y con independencia de que sean o no verdaderos, el ordenamiento les otorga certeza-como explicitaremos mediante ejemplos-y a los que consiguientemente adorna de efectividad, como si se asentaran en una verdad histórica o material.

La simple enumeración que anteriormente se ha hecho del elenco de la variada tipología de las diversas verdades que acoge el derecho -las «verdades verdaderas» o históricas y las diferentes «verdades oficiales»- nos muestra que, al igual de lo que ocurre en la vida social, también en relación

${ }^{44}$ Aparte de las presunciones de mera referencia ideológica, como la presunción de inocencia (art. 24.2 Const.), las presunciones encuentran en general su base en intereses socioeconómicos que el ordenamiento - quieta non muovere- acoge en razón del mantenimiento del statu quo, por ejemplo favoreciendo legalmente a la posesión (arts. 434 y 448 Cc.), o bien teniendo en cuenta consideraciones de tipo técnico que se basan en el criterio de la mayor probabilidad deducible del id quod plerunque accidit.

${ }^{45}$ La frecuente contratación simulada o fiduciaria es consentida, en efecto, en aras del principio de la autonomía de la voluntad, siempre que respeten los límites del art. 1255 Cc. que lo proclama.

${ }^{46}$ Las presuposiciones, que en el fondo son invenciones legislativas o jurisprudenciales, aunque puedan justificarse en plausibles apreciaciones o conjeturas, se basan, las más de las veces, en la simple e interesada intuición del legislador o del juzgador.

${ }^{47}$ Cfr. Louis-Lucas, Verité matérielle et verité juridique, en Mélanges offerts à René Savatier, París, Dalloz, 1965, págs. 583 a 601, esp. pág. 584, de donde tomo las expresiones recogidas en el texto. 
al derecho se puede decir, como ya enseñara en sus reflexiones morales Michel de Montaigne (1533-1592), que «el reverso de la verdad tiene cien mil caras y un campo indefinido» de plasmación ${ }^{48}$. Por lo demás, no es arbitrario decir que «no existe una realidad absoluta objetiva y única» en cuanto que el lenguaje que la representa «no es un retrato o una fotografía de los hechos», puesto que «nuestras descripciones están empapadas de teoría hasta el punto de poderse considerar que el mundo está contaminado de las palabras que usamos para describirlo» ${ }^{49}$.

Piénsese, por poner un ejemplo que puede considerarse banal, por referirse a supuestos habituales en la actividad económica, en los reversos de la verdad que suponen la sociedad -anónima o de responsabilidad limitadadenominada unipersonal o la sociedad de varios socios del todo dominada, acaso mediante los sutiles instrumentos de la llamada ingeniería financiera, por una sola persona: la primera, según razón, no podría existir ni responder a la verdad, en cuanto que sociedad y unipersonalidad son conceptos contradictorios $^{50}$ que respectivamente se excluyen, pero que para el derecho

${ }^{48}$ Cfr. Montaigne, Ouvres completes, Essais, livre I, chapitre IX, Bruges, Gallimard, 1962, pág. 28. La opinión problemática señalada en el texto contrasta con la sentenciosa pero acrítica consideración según la cual veritatis una vis, una facies est: cfr. SENECA, Epistulae morales ad Lucilum, lib. XVII-XVIII, ep. 102, 13 (trad. it. de Barone con texto latino al frente) (6 $6^{\mathrm{a}}$ ed.), Milano, Garzanti, 2003, pág. 782.

Con la finalidad de proteger el derecho al honor frente al ejercicio del derecho, también constitucionalmente declarado, de la libertad de expresión, se exige que la eventual información sobre unos hechos sea «veraz» o que ella se corresponda con la «veracidad». Sin embargo, basta con que tal veracidad sea tendencial, pues su concepto no coincide, según tiene precisado la jusrisprudencia constitucional -así, entre otras, en las STC. de 23 de junio de 2008 y de 26 de enero y de 1 de junio de 2009- con el de verdad objetiva, por cuanto que, como ha declarado recientemente la STS. de 8 de abril de 2011, «por veracidad debe entenderse el resultado de una razonable diligencia por parte del informador para contrastar la noticia de acuerdo con pautas profesionales, ajustándose a las circunstancias del caso, aun cuando la información, con el transcurso del tiempo, puede más adelante ser desmentida o no resultar confirmada». Como se aprecia fácilmente, se recurre a redimensionar la exigencia de veracidad a través de la llamada técnica de la ponderación.

${ }^{49}$ Cfr. Pintore, Il diritto senza verità cit., pág. 130, que, haciendo referencia a Descartes y a Kant, también significa (pág. 131) que «el conocimiento humano no puede ser entendido como una componente objetiva del mundo que con su estructura permanente y sus valores intrínsecos la convalidaría; por el contrario, sabemos ahora que el mundo externo debe colocarse en el interior del conocimiento y que los criterios para distinguir el conocimiento verdadero del falso son independientes de la estructura del mundo y que la preceden».

${ }^{50}$ La RDGRN. de 21 de julio de 1990 consideró, sin embargo, que «la sociedad unipersonal constituiría así, probablemente, una contradictio in terminis, pero no una contradictio in substantia, bajo la curiosa argumentación formal de la «objetivación de la 
constituye una entidad indudablemente $\operatorname{cierta}^{51}$; y en cuanto a la segunda, su apariencia de sociedad es tranquilamente admitida como certeza por el derecho, que sólo intenta descubrir la verdad que bajo ella se oculta, mediante el llamado «levantamiento del velo», cuando considera que tal reverso de la verdad resulta dañino e intolerable y con «el fin de evitar -según expresión de que se sirve habitualmente la jurisprudencia- que, bajo la protección de esta ficción o forma legal, puedan ser perjudicados intereses públicos o privados en términos de fraude $\rangle^{52}$. Todo ello sin abundar en la consideración

condición de socio que se lleva a cabo mediante la acción. La acción, indivisible, acumulable, transmisible, permite objetivar la relación de participación en la sociedad anónima respecto de la persona de su titular. Una persona - podría decirse- es tantas veces socio como acciones posea. Cada puesto de socio subsiste como tal y no se ve alterado porque se acumulen varios. De ello cabe deducir que la reunión en una misma mano de todas las acciones, en la medida en que no afecta a la existencia de múltiples participaciones independientes o puestos de socio, no determina la invalidez conceptual de la sociedad unipersonal».

${ }^{51}$ La llamada sociedad unipersonal es objeto de importantes normas de nuestro derecho mercantil, en particular las que constituyen las normas fundamentales sobre la misma, contenidas en el Cap. III (arts. 12 a 17) del texto refundido de la ley de sociedades de capital, aprobado por el Real Decreto Legislativo 1/2010, de 2 de julio, según el cual «se entiende por sociedad unipersonal de responsabilidad limitada o anónima: a) la constituida por un único socio, sea persona natural o jurídica. b) la constituida por dos o más socios cuando todas las participaciones o las acciones hayan pasado a ser propiedad de un único socio. Se consideran propiedad del único socio las participaciones sociales o las acciones que pertenezcan a la sociedad unipersonal» (art. 12). La existencia posible de la sociedad unipersonal consiente la eventual contratación entre su único socio y la sociedad de que dicho socio es único titular, en una suerte de autocontratación entre el socio único, como persona individual, y él mismo en cuanto administrador de la sociedad (art. 16).

El instituto de la sociedad unipersonal -al que no deja de prestar particular atención el derecho comunitario: cfr., por ejemplo, la directiva 2009/102/CE del Parlamento Europeo y del Consejo, de 16 de septiembre, relativa a la sociedad de responsabilidad limitada de socio único- consiente aislar el «patrimonio personal» de su único socio del «patrimonio social» de la sociedad de cuyas participaciones o acciones representativas del capital social es aquél el único titular. En esta diferenciación, que consiente la inmunidad del patrimonio personal del socio único respecto de las obligaciones derivadas de las actuaciones sociales que él exclusivamente gestiona, radica el interés práctico de la constitución de tal tipo de sociedad.

${ }^{52}$ Cfr., por ejemplo, la STS. de 4 de marzo de 1988, cuyos conceptos suelen repetirse con mucha frecuencia en otros pronunciamientos jurisprudenciales y así, últimamente, en la STS. de 3 de abril de 2009. Los estudios sobre la doctrina del «levantamiento del velo de la persona jurídica», de ascendencia germánica, son relativamente abundantes entre nosotros: se señalan, en particular, las contribuciones de DE ÁNGEL YAGÜEZ, La doctrina del levantamiento del velo en la jurisprudencia (4a ed.), Madrid, Cívitas, 1997, y Boldó RoDA, Levantamiento del velo y persona jurídica en el derecho privado español (4 ${ }^{\mathrm{a}} \mathrm{ed}$.), Cizur Menor, Aranzadi, 2006. 
de que las persona jurídicas, por más que se quiera ver en ellas una realidad original directamente derivada de la existencia de hecho de un grupo de personas, de una convergencia de intereses o incluso de un simple objetivo independiente a satisfacer, no dejan de tener un carácter artificial y ficticio $\mathrm{y}$, en definitiva, puramente formal, aunque estén postuladas por atendibles exigencias económicas o sociales.

Como se indicaba antes, no nos debe sorprender a los juristas este desdoblamiento entre «certeza»y «verdad», si advertimos que, aunque la realidad es más compleja, el derecho no toma propiamente en cuenta sino un universo depurado, «lo que corresponde a la diferencia entre el universo real y su representación ${ }^{53}$; si consideramos la posible utilidad del recurso a la representación de tal escisión por parte del legislador, como evidencia de manera ejemplar el art. $460,4^{\circ}$, del Código civil -en cuya regla conviven casos de posesión que responden a una «verdad histórica o real» y otros que se reportan a una «realidad virtual o jurídica», que, sin ser verdadera, se presenta legalmente como «cierta» ${ }^{54}$-; y si pensamos también, en el concreto plano de la praxis, que en un pleito cada parte alega, relata e intenta probar unos hechos y defiende, a través de la argumentación persuasiva de su abogado $^{55}$, «su propia verdad» y rebate y contradice lo que para la parte adversa es asimismo «su verdad» ${ }^{56}$, de cuyas dos opuestas «verdades» o hipótesis de

${ }^{53}$ Cfr. Izorche, Le raisonnement juridique, París, P.U.F., 2001, pág. 63. Véase también la contribución, anteriormente citada, de LouIs-LuCAS, Verité matérielle et verité juridique.

${ }^{54}$ Se contemplan en esta norma una posesión que, en efecto, se pierde pero se conserva-que muere pero que a la vez vive- y una posesión que se adquiere pero que no se tiene-que nace pero que a la vez no vive-, con lo que el legislador recurriría aquí, de seguirse la conceptuación propuesta por Gracián, Agudeza y arte de ingenio ( $4^{\mathrm{a}} \mathrm{ed}$.), Madrid, Espasa Calpe, 1957, págs. 31 a 42, a una «agudeza de improporción o disonancia».

${ }^{55}$ La problemática de la argumentación jurídica suscita en la actualidad una atención generalizada entre los teóricos del derecho, sobre todo a partir de los estudios de PerelMAN, La lógica jurídica y la nueva retórica (trad. esp. de Diez-Picazo), Madrid, Cívitas, 1979. A esta temática se ha dedicado el reciente libro de ATIENZA, El derecho como argumentación, Barcelona, Ariel, 2006, autor que ha venido dedicando a estas cuestiones diversos trabajos anteriores. Véase también, AlEXY, Teoría de la argumentación jurídica, Madrid, Centro de Estudios Políticos y Constitucionales, 1997, así como MACCormick, Raisonnement juridique et théorie du droit (trad. fr. de Gagey), Paris, P.U.F., 1996.

${ }^{56}$ Cuyas «verdades» defendidas por uno y otro abogado postulante constituyen enunciados hipotéticos que pueden ser, en sí mismos, verdaderos o falsos: vid., a este propósito, TARUfFo, Simplemente la verdad cit., pág. 145. No han que olvidarse que, en sus actuaciones, el abogado - que propiamente formula, en palabras del propio autor (pág. 69), una «pretensión de verdad»- intenta sobre todo persuadir al juez de que su decisión debe acoger cuanto postula a favor de su cliente, sobrevalorando los datos y hechos que le benefician, minusvalorando o distorsionando los que le perjudican o también excluyendo de su argumentación los que no le convienen. 
decisión será en definitiva «cierta»o «verdad oficial» ${ }^{57}$ la que, a través del proceso $^{58}$ y mediante la «interpretación de los hechos» que ante él se presen$\tan ^{59} \mathrm{o}$ de las normas legales que debe aplicar ${ }^{60}$ decida el juez ${ }^{61}$, aunque aca-

${ }^{57}$ En el conocido libro de Calamandrei, Elogio dei giudici scritto da un avvocato (con introduzione di Barile), Firenze, Ponte alle Grazie, 1989, págs. 17 s., señala la «verdad oficial» que supone la sentencia y se refiere, recordando las modalidades regladas de las apreciaciones judiciales, a las muchas «pantallas»-dice- que se interponen «tra la previsione dell'avvocato e la verità ufficiale, che alla fine sarà scritta nella sentenza». Esta preciosa obra se publicó por primera vez en 1935 y la versión utilizada es una reproducción de su $4^{\text {a }}$ ed. de 1959, reimpresa, por tercera vez, en 1995.

${ }^{58}$ La dimensión epistemológica del proceso en orden a alcanzar el juzgador un cabal conocimiento y apreciación de los hechos relevantes para la solución de la controversia - los facta probanda - es resaltada por TARUFFO, Simplemente la verdad cit., págs. 155 a 218 , donde a este propósito hace una interesante exposición sobre la actividad probatoria y los personajes intervinientes en la misma.

${ }^{59}$ Aunque se trate de una acepción bastante laxa del concepto de interpretación, es bastante habitual referirse a ella en relación a la valoración de los hechos, en particular «para describir los pasos del juez en la solución de los asuntos que se le someten»: AMSELEK, L'interprétation à tort et à travers, en Interprétation et droit cit., pág. 13. Sobre el tema es destacable la contribución de IVAINER, L'interprétation des faits, París, L.G.D.J., 1988.

En el ya recordado y delicioso libro de CAlamandreI, Elogio dei giudici scritto da un avvocato cit., págs. 117 s., se expresa que en el proceso «la verdad tiene tres dimensiones», las de cada uno de los abogados, que presenta la verdad según la ve «de perfil» y en relación a los intereses de su cliente, y la del juez que contempla las cosas «de cara», de frente o en su conjunto.

${ }^{60} \mathrm{La}$ actividad interpretativa, por su propia dinámica, puede eventualmente conducir, en función de la obligación de resolver en derecho que afecta al juez, a que éste llegue a apreciar en las normas, dada la dimensión creadora que con frecuencia tiene la interpretación, una «verdad imaginaria». Se ha llegado a afirmar a este respecto que «un principe d'économie conduit souvent à faire dire au texte de loi plus qu'il ne dit ou autre chose que ce qu'il dit plutôt qu'à modifier le texte, mais dans ce cas on n'oppose pas sens apparent et sens caché»: cfr. MaInGUENEAU, L'interprétation des textes littéraires et des textes juridiques, en Interprétation et droit cit., págs. 61-71, esp. pág. 67.

${ }^{61}$ Como justamente expresa Hernández Gil, El abogado y el razonamiento jurídico, Madrid, 1975, pág. 5, «la sentencia no constituye la verdad inconcusa, sino la solución impuesta, revestida de autoridad, dentro de la organización de la justicia».

A tal idea ha respondido siempre la figura de la llamada «cosa juzgada», que viene a significar que lo declarado por un juez o tribunal en la sentencia frente a la cual no cabe plantear recurso tiene el valor de solución indiscutible y definitiva, por lo que se dice de ella que ha «pasado en autoridad de cosa juzgada» y que su contenido ha de tenerse, por adquirir «certeza», por «verdadero», de acuerdo con la vieja máxima de que res judicata pro veritate accipitur. En este sentido, bien se puede decir que «la regla de la autoridad de la cosa juzgada confiere a una opinión el estatuto de verdad»: cfr. McEvoy, La question de l'arrêt: le cas de l'argumentation dans le droit, en Lire le droit: langue, texte, congni- 
so su sentencia no acoja, ya sea un función de la aludida interpretación de los hechos $^{62}$ y de las normas o ya sea por consecuencia de incurrir en el llamado

tion (dir. Bourcier y Mckay), París, L.G.D.J., 1992, págs. 173-196, esp. pág. 193. Para referirse al valor de la cosa juzgada se ha dicho también, a veces, que lo que ella afirma es la «verdad social»: cfr. Rocco (Alfredo), Trattato della cosa giudicata come causa di stinzione dell'azione penale, Modena, 1904, pág. 273, para quien, «quando le forme rese obbligatorie dalla legge processuale furono osservate, la cosa giudicata rappresenta la legalità essa medesima, e non solo la verità è giudizialmente accertata; ma è altresi la verità nell'opinione e nella fede dei cittadini; è socialmente e giuridicamente la verità».

Lo decidido judicialmente de manera definitiva se ha considerado siempre, en la dirección expresada en el texto, como intocable por razones de interés público, bajo la consideración de que volver sobre lo juzgado era algo pernicioso desde el punto de vista de tal interés: de ahí la afirmación de que res judicatae instaurari ejemplo grave est (Codex, 1. 4 de re judicata). En efecto, fuera de los muy tasados casos en que, en el ámbito civil, sea procedente el denominado recurso de revisión -únicamente admitido en supuestos de disposición de documentos decisivos que no pudieron alegarse en el pleito de haberse utilizado documentos declarados falsos en un proceso penal, de haberse fundamentado la sentencia en las afirmaciones falsas de testigos o de peritos o de haberse obtenido la sentencia injustamente en virtud de cohecho, violencia o maquinación fraudulenta (arts. 509 ss. Lec.)-, la sentencia firme es definitiva e irreversible en cuanto a la solución o «verdad judicial» que en ella se contiene, de modo que lo decidido en la resolución judicial es inamovible (cosa juzgada formal: art. 207 Lec.) y excluye que el objeto de la decisión pueda dar lugar y replantearse en un ulterior proceso (cosa juzgada material: art. $222 \mathrm{Lec}$.).

${ }^{62}$ Esta suerte de interpretación puede dar lugar a que, respecto de una misma realidad, formule el juzgador unas diversas o diferentes «verdades», que, en el caso de que sus distintas sentencias sean definitivas, adquirirá cada una el valor de la «certeza» desde el punto de vista oficial.

Unos casos recientes, relativos a unos concursos de acreedores, nos advierten de esta posibilidad. La SAP. de Barcelona (sec. 15ª de 19 de junio de 2009 había considerado que, dado que el contrato de «leasing» es un contrato de tracto sucesivo, «cada cuota mensual o renta es la contraprestación pactada por la cesión durante ese mes del bien», por lo que las cuotas vencidas antes de la declaración del concurso tendrán la consideración de créditos concursales (o créditos con privilegio especial respecto del bien), mientras que las posteriores pasan a tener la consideración de créditos contra la masa. Sin embargo, la propia sección de la Audiencia, en sentencia formulada por el mismo ponente, declaró en la SAP. de Barcelona de 9 de noviembre de 2010 que, «aunque lo que se transmite es una cesión de uso, la cuota pactada no responde tanto al concepto de renta que compensa la privación temporal del bien por parte del propietario, como a permitir a la entidad financiera recuperar el precio satisfecho por la adquisición del bien, además de una carga financiera que constituye propiamente el beneficio de la arrendadora financiera». Por ello, según esta segunda sentencia -en la que se dice que se repiensa lo dicho en la anterior dada la real configuración de la cuota-, todas las cuotas mensuales han de ser consideradas como créditos privilegiados, a diferencia de lo que se había decidido en la sentencia anterior.

En relación a la eventual diferencia en la valoración judicial de unos mismo hechos, la STC. de 28 de octubre de 2009 declara que un tribunal puede percibir los hechos de 
error judicial o en una actuación prevaricadora, la verdad de la parte que la tiene sino precisamente la tesis de la parte a la que no asiste la verdad ${ }^{63}$.

De las anteriormente relacionadas «certezas públicas» derivadas de «verdades oficiales ${ }^{64}$ se puede decir, en definitiva, que constituyen el resultado

forma distinta a como anteriormente ha hecho otra jurisdicción cuya decisión se alega, pero que tal diferente apreciación debe ser motivada.

${ }^{63}$ A propósito de los pleitos y de los abogados que postulan en ellos se podría todavía indicar que un mismo hecho se puede apreciar por el letrado según perfiles conceptuales distintos y, por tanto, ser representado jurídicamente mediante configuraciones o «verdades» diferentes.

Un caso judicial puede resultar a estos efectos ejemplar. En el supuesto de autos, «sucedió que en un matrimonio en el que se habían otorgado capitulaciones matrimoniales designando heredero al primer hijo varón, habían nacido cuatro hijas antes de que naciera el futuro heredero; quejoso el padre de la actitud del hijo y heredero capitular, entregó a un íntimo amigo una respetable cantidad, al objeto de que, a su muerte entregara a cada una de las hijas, al momento de contraer matrimonio, o a la llegada de la mayoría de edad, una cuarta parte de aquel capital. Fallecido el padre, el amigo escrupuloso abrió una cuenta bancaria en la que ingresó la cantidad recibida, y al casamiento de cada hija, le entregó el capital correspondiente, pero ocurrió que entregada la parte correspondiente a la última hija, quedó en la cuenta bancaria una pequeña cantidad producto de los intereses satisfechos por el Banco. El amigo escrupuloso, remitió este saldo al heredero dándole cuenta de lo ocurrido. El hijo heredero promovió demanda en reclamación del total capital entregado por el padre, argumentando que se trataba de un mandato del padre que había quedado extinguido a su fallecimiento. El abogado del amigo, equivocando la elección de (la) norma aplicable, argumentó que se trataba efectivamente de un mandato, pero post mortem, y naturalmente perdió. Si la norma elegida para aplicar hubiera sido la calificación de los hechos como donación ab causam, hubiera ganado. El amigo escrupuloso hubo de satisfacer al heredero el total capital conferido por el testador». Tomo este ejemplo de Casals Colldecarrera, La interpretación, en Ciclo de conferencias sobre el nuevo título preliminar del Código civil, Barcelona, Ilustres Colegios de Abogados y Notarial de Barcelona y Academia de Jurisprudencia y Legislación de Cataluña, 1975, págs. 81 ss., esp. págs. $28 \mathrm{~s}$. El asunto en cuestión dio lugar a una STS de junio de 1915.

Como era previsible, en el supuesto indicado, el abogado defensor del amigo del difunto fracasó en su intento, al entender adecuadamente el juez que los efectos del mandato acaban con la muerte del mandante (art. $1732,3^{\circ} \mathrm{Cc}$.), habiéndose probablemente ganado, en cambio, por él el pleito, si el abogado hubiera presentado el caso como una donación ob causam, esto es, como una donación hecha para que, a su vez, el donatario entregue la cosa recibida a otra persona. De cualquier forma, fuera «verdadero» uno u otro de los negocios eventualmente representados como celebrados entre los dos amigos, el que de ellos habría sido en definitiva «cierto» sería el que hubiera sido apreciado por el juez o, en caso de apelación, por el tribunal de segunda instancia, cuando hubiera adquirido la sentencia el carácter de la cosa juzgada.

${ }^{64}$ Las que pueden llamarse «verdades legales» o «verdades oficiales» no son propiamente tales sino que, precisamente, únicamente constituyen «certezas»: cfr., sobre este aspecto, RoMANO TASSONE, Amministrazione pubblica e produzione di «certezza» cit., pág. 29. 
materializado de una representación deformada de la realidad -o incluso de un rechazo de la misma- que es eficiente desde el punto de vista normativo y organizador de la sociedad y que, desde la perspectiva de tal finalidad y en cuanto que provienen de los poderes públicos o son consentidas por ellos, participan tales «certezas» de una especial autoridad, si bien, en cuanto que lo que se expresa a través de las mismas es el buscado resultado de dicha deformación o del aludido rechazo de la realidad meramente conveniente desde el punto de vista preceptivo, se constituyen -salvo en algunos casos, como, en particular, el de las verdades ficticias-como «certezas reversibles» para el caso de que tal desviación de la verdad, en principio adoptada como útil, se manifieste como inadecuada o contraproducente.

En este sentido, no se trata de ordinario y necesariamente de meras invenciones o de puros sucedáneos de la verdad, de modo que, si con ellas se prefiere, de entrada, obviar el descubrimiento de la verdad o no se quiere aportar lo verdadero, también se pretende mediante ellas construir entidades que no sean del todo extrañas al entramado social -cuyo desenvolvimiento se pretende propiciar mediante la provocación de la certeza y de la seguridad jurídicas ya antes indicadas- y que sean solamente «verdades vicarias» o instrumentales, sino que se constituyen, por tanto, en «cuanto más probablemente verdaderas posibles». Es en razón de estas mismas consideraciones de utilidad normativa -y de manera consecuente- por lo que tales entidades, sólo en algún sentido instrumental artificiales, se configuran precisamente como transformables o reversibles, por si su persistente artificialidad puede llegar a ser perniciosa o inconveniente, para cuyo caso -mediante, verbi gratia, la prueba destructora de la presunción iuris tantum o la demostración de la simulación- se pueden desmoronar a través de una oportuna «verificación» ${ }^{65}$.

En definitiva, y en un contexto descriptivo más general, pero en el que se incardinan perfectamente las indicaciones anteriores, se puede afirmar que las mismas inducen directamente la idea de que el jurista $-\mathrm{y}$, por tanto, el legislador- es, en cuanto «artista de la razón» ${ }^{66}$, también artista de la pala-

${ }^{65}$ Tomo aquí alguna ideas y utilizo expresiones encontradas en GiAnNINI, S.v. «Certezza pubblica» cit., pág. 771 .

${ }^{66}$ Cfr. Legendre, Il giurista artista della ragione (a cura di Abitabile, con saggio introduttivo di G.B. Ferri), Torino, Giappichelli, 2000, passim. El sistema jurídico, viene a decir este autor (pág. 113), representa el poder «más extremo que haya: el poder de separar las palabras y las cosas, fundamento del poder sobre el hombre».

Es evidente que este planteamiento tiene profundas raíces filosóficas -las de la superación de la tradicional relación entre intelectus y res, entre mente y realidad o entre pensamiento y ser y las más modernas de la separación entre lenguaje y realidad- a las que en esta pequeña obra únicamente se puede hacer una simple alusión.

Sobre el arte del derecho ha escrito Carnelutti, conmemorando a Vittorio Scialoja, brillantes palabras que se recogen ahora en CARnelutTi, Discorsi intorno al diritto, Padova, 
bra $^{67}$ y nos hacen recordar las brillantes expresiones de un gran dramaturgo francés contemporáneo cuando afirmaba que «el derecho es la más potente de las escuelas de la imaginación» y que «jamás un poeta ha interpretado tan libremente la naturaleza como un jurista la realidad» ${ }^{68}$.

\section{LA CERTEZA DE LAS VERDADES OFICIALES.}

\subsection{Breves indicaciones taxonómicas.}

Las verdades oficiales a las que nos venimos refiriendo, de las que jurídicamente se deriva certeza con independencia de su correspondencia con la realidad $^{69}$, se afirman, unas veces, directamente por las normas, como es el

Cedam, 1937, págs. 29 ss. También insiste sobre ello en La certezza del diritto cit., págs. 204 s.; en donde confiesa que «un passo decisivo è stato, nella storia del mio pensiero, aver chiarito il valore della poesia, ch'è ogni guisa di rappresentazione concettuale della realtà (cursiva del autor). Già, il legislatore ha da essere un poeta. Dipingere un ritratto o construire un articolo di legge è la stessa cosa: si tratta sempre di tradurre nel finito l'infinito». Véase también Carnelutti, Meditazioni, I, Roma, Tumminelli, 1943, págs. $58 \mathrm{ss}$.

Por lo demás, la realización del derecho se lleva a cabo mediante narraciones -la demanda, la contestación, la eventual reconvención y consiguiente contestación, los escritos de conclusiones o de resumen de pruebas, la sentencia, el laudo, el dictamen (calificado, por cierto, en algunos países «pro veritate») o el informe en un expediente administrativo- que reconstruyen desde el punto de vista de su autor los hechos que se tienen en cuenta. Por eso se ha podido decir por un conocido jurista, con apreciación trasladable a cualquier contexto, que «el narrador da forma a la realidad»: cfr., TARUFFO, Simplemente la verdad cit., pág. 67, en donde se cita a otros autores.

${ }^{67}$ Cabe aquí señalar que «la verité ne peut étre determinée en dehors du langage», según certera expresión que se recoge por PETEV, L'interprétation des faits et l'interprétation du droit, en Interprétation et droit cit., pág. 52, n. 7.

${ }^{68}$ Cfr. Giradoux, La guerre de Troie n'aura pas lieu, acto II, escena $5^{\mathrm{a}}$, en Le theatre complet, vol. 6, Neuchatel et París, Ides et Calandes, 1946, pág. 81.

Con palabras no menos sugestivas, un joven y prestigioso historiador ha comentado, a propósito de ciertas experiencias socio-políticas, que «non è la realtà a superare la fantasia bensí l'inesauribile e potentissima fantasia degli uomini a inventare la realtà»: cfr. Gotor, Il memoriale della repubblica, Torino, Einaudi, 2011, pág. 72.

${ }^{69}$ La certeza que se tiene en cuenta en este pequeño estudio supone, según es fácil de apreciar, la indicación a los particulares de las referencias sobre cuya apreciación han de tomar sus decisiones y conducir sus actuaciones, de modo que la misma no puede confundirse con los supuestos negociales -tales como la repetición del negocio jurídico, el reconocimiento de un derecho o de un hecho o la confesión extrajudicial- que se dirigen a determinar, a afirmar o a «fijar» situaciones preexistentes, eventualmente inciertas o discutibles, para determinar su certeza: sobre estas cuestiones se recuerdan los magníficos trabajos de FalzeA, s.v. «Accertamento», en Enciclopedia del diritto, I, Milano, Giuffrè, 1958, págs. 205-219, y de GiorgianNI, s.v. «Accertamento (negozio di)», ibi, págs. 227-243. 
caso de las verdades presupuestas -que descienden de la ley o de los principios generales detectados por la jurisprudencia-, el caso de las verdades aparentes, el caso de las verdades ficticias -salvo los escasos supuestos de ficciones negociales-, el caso de las verdades presuntas y, desde luego, el caso de las denominadas verdades falsas. En otras ocasiones tales verdades alcanzan relevancia en cuanto constituidas, en ejercicio de la autonomía que les compete, por los particulares, como son los supuestos de las verdades simuladas y de las verdades fiduciarias.

Desde otro punto de vista, las verdades oficiales -que aquí se examinan fundamentalmente en la circunscrita perspectiva del derecho civil $^{70}$ - pueden ser, según ya se ha sugerido antes, reversibles, por poder ser descabalgada su transcendencia en orden a reconducir las cosas a la verdad sustancial, o, por el contrario irreversibles, en cuyo caso es persistente la divergencia entre la verdad oficial constituida en certeza por las normas y la realidad histórica o material. En este sentido, son reversibles las verdades aparentes, las presuntas, las simuladas y las fiduciarias; e irreversibles, en cambio, las verdades presupuestas, las ficticias y las falsas. En efecto, mientras la presunción es una suposición de verdad que autoriza a dar paso a la prueba contraria, la ficción es decisiva independientemente de su falta de exactitud.

Tras la expresión de estas sucintas precisiones clasificatorias, respecto de las que las figuras diferenciadas no siempre son entre sí excluyentes ${ }^{71}$, se hace a continuación un esbozo de las «verdades oficiales» más características, limitadamente a aquéllas - entia non sunt multiplicanda praeter necessitatem- que pueden considerarse como más nítidamente configuradas ${ }^{72}$.

\subsection{Las verdades presuntas.}

Entre las ya antes indicadas verdades oficiales, las verdades presuntas se proclaman frecuentemente por el derecho mediante las normas que conside-

${ }^{70}$ No se estudian, por tanto, las cuestiones, más básicas y fundamentales, que se refieren, de una parte, al desinterés o incluso rechazo de la consideración de la verdad en el discurso filosófico o en el jurídico -desinterés o rechazo derivados de concepciones relativistas, constructivistas o nihilistas $-\mathrm{y}$, de otra a la conveniente afirmación del valor de la verdad en el ámbito de la moral, de la política, de la administración de justicia, de la economía y, en general, en la vida social.

${ }^{71}$ Por ejemplo, parecen del todo conjugables, por poder tener correspondencia entre sí, la verdad aparente y la verdad ficticia, en cuanto que la aparente se tiene en cuenta «como si» respondiera a la realidad. En relación a la figura del «funcionario aparente», a que luego se hace referencia, y a propósito de un matrimonio civil autorizado por quien no estaba habilitado para ello, subraya la interconexión ahora aludida Perelman, La lógica jurídica y la nueva retórica cit. § 91, pág. 222, que justamente hace mención de la creencia en la legalidad de la investidura del autorizante de la boda.

${ }^{72}$ No se hace referencia por eso a las que podrían acaso denominarse «verdades contrahechas», por ser configuradas negocialmente por los particulares utilizando un tipo contractual para perseguir los efectos de otro. De estos supuestos, que la doctrina agrupa 
ran verificados ciertos hechos cuya verdad no es segura y cuya averiguación el derecho ni siquiera promueve directamente ${ }^{73}$.

Tal ocurre con las numerosas presunciones legales, aún en el caso de las llamadas iuris tantum, a las que con tanta habitualidad recurre el ordenamiento positivo, con la determinación, de economía procesal, de aligerar el onus probandi o bien con la intención de excluir del contenido de dicha carga aquello que es difícil de probar o conviene presumir en atención a las conveniencias del tráfico. Las presunciones constituyen, en efecto, en cuanto adoptadas por el legislador «al considerar que en ocasiones es posible cruzar sin imprudencia la frontera teórica que separa la probabilidad de la certidumbre», una «verdad suficiente» de la que se tiene necesidad ${ }^{74}$, una «suposición de verdad» que da lugar, en definitiva, a una «certeza», aunque el valor de ésta pueda eventualmente claudicar, ya que, como se conviene

bajo el rótulo de «negocios indirectos», serían ejemplos la venta de una finca nummus unus o por un euro con el propósito de donar, el nombramiento de un administrador con relevación de la obligación de rendir cuentas al igual objeto de beneficiarle o la constitución de una sociedad anónima con parientes o dependientes que nada aportan al capital. La catalogación de los negocios indirectos dista de ser asumida de manera compartida por la doctrina y, para algunos, puede confundirse, como en el caso del último ejemplo aludido de la sociedad «de favor», con el negocio fiduciario, de manera, por otra parte, que los diferentes supuestos de donación indirecta -más abundantes en la práctica que los antes aludidos, como la renuncia unilateral al cobro de una deuda o la renuncia a la cuota de participación en un bien común, para favorecer al deudor o a los demás copropietarios- están lejos de constituir «una categoría unitaria objeto de una regulación específica en todo su régimen»: cfr., sobre este último aspecto, LACRUZ BERDEJO, SANCHO Rebullida, luna Serrano, Delgado Echeverría, Rivero Hernández y Rams Albesa, Elementos de derecho civil, II-2 (4a ed. revisada y puesta al día por Rivero Hernández), Madrid, Dykinson, 2009, pág. 110 s.

Sobre la aludida categoría negocial es clásica la obra de RuBINo, Il negozio indiretto, 1938, con versión española de Rodríguez Arias, Madrid, 1953, y sobre la última figura indicada puede verse la contribución de Ortega PARDo, Donaciones indirectas, en Anuario de Derecho Civil, II-3 (1949), págs. 918 ss.

${ }^{73}$ Mediante la presunción, en efecto, se tiene por cierto un hecho que la parte beneficiada por aquélla debería en principio probar, pero de cuya eventual prueba se le dispensa atribuyéndose a la otra parte la demostración de lo contrario. Por eso se ha podido decir que la presunción, al dar por existente lo que no se prueba, tiene una dimensión contraepistémica: cfr. TARUfFo, Simplemente la verdad cit., pág. 260.

El ordenamiento, en efecto, da por bueno el hecho incierto que resulta de la presunción, de modo que el favorecido por ella no lo tiene que probar: cfr. art. 385.1 Lec., si bien las normas son conscientes de que el hecho presunto puede no corresponderse con la realidad, por lo que han previsto que el perjudicado por la presunción pueda conseguir destruirla mediante la prueba en contrario: cfr $385.3 \mathrm{Lec}$.

${ }^{74}$ Cfr. Louss-Lucas, Verité matérielle et verité juridique cit., pág. 587. 
desde antiguo, praesumptum esse debet nisi contrarium approbetur ${ }^{75}$, pudiéndose decir que la posibilidad de la prueba contraria es la nota característica de la presunción legal.

Los ejemplos de afirmaciones de certezas legales basadas únicamente en verdades presuntas, que se asientan en la probabilidad que se infiere de datos conocidos con el apoyo de la experiencia o en la verosimilitud ${ }^{76} \mathrm{de}^{\mathrm{a}}$ los mismos en su correspondencia con la normalidad del id quod plerunque accidit $^{77}$ y que, en cuanto tales, pueden o no corresponderse con la realidad, podrían multiplicarse. Se pueden recordar aquí desde el caso de la presunción de la muerte de una persona desaparecida o ausente ${ }^{78}$ al de la presunta consideración de que el mandato es gratuito ${ }^{79}$; desde la presunción de continuidad posesoria o de posesión intermedia ${ }^{80}$ a la que considera que el arrendatario recibe en buen estado la cosa arrendada ${ }^{81}$; desde la presunción de comunidad a la opuesta de pertenencia exclusiva de la pared medianera ${ }^{82}$; desde la presunción de culpa del deudor de la cosa que se pierde en su poder y debe entregar ${ }^{83}$ a la de la voluntariedad de la entrega por el acreedor del documento acreditativo de la deuda que se halla en poder del deudor ${ }^{84}$; desde la

${ }^{75}$ Cfr. Hedemann, Las presunciones en el derecho (tras. esp. de Sancho Seral), Madrid, Editorial Revista de Derecho Privado, 1931, págs. 16, 29 y 46.

En la doctrina italiana es clásica la obra de RAMPONI, La teoria generale delle presumzioni nel diritto civile, Torino, $1890 \mathrm{y}$, entre nosotros, es fundamental el estudio de Serra Domínguez, De las presunciones, en Comentario al Código civil y Compilaciones forales (dir. Albaladejo), XVI-2, Madrid, Edersa, 1991. Véase también, de este último autor, Comentario del Código civil (antiguos arts. 1249 y 1250), II, Madrid, Ministerio de Justicia, 1991, págs. 414 ss.

76 Veresimile est, nisi evidentissimis probatonibus ostenderit (Digesta, 12, 14, 6).

${ }_{77}$ Aunque en una línea no coincidente, hace apreciaciones interesantes sobre la distinción entre verosimilitud y probabilidad TARUFFo, Simplemente la verdad cit., págs. 105 a 108.

78 Cfr. arts. 193 y 194 Cc.

$79 \mathrm{O}$ bien que se presume la obligación de renumerarlo cuando «el mandatario tiene por ocupación el desempeño de servicios de la especie a que se refiere el mandato»: cfr. art. $1711 \mathrm{Cc}$.

${ }^{80}$ Cfr. arts. 459 y $1960,2^{\circ}$, Cc.

81 Cfr. art. $1562 \mathrm{Cc}$.

${ }^{82}$ Cfr. arts. 572,573 y 574 Cc.

${ }^{83}$ Cfr. art. 1183 Cc. La jurisprudencia tiene declarado que, aunque el precepto se refiere a obligaciones de dar, su norma «se extiende, no tanto por analogía sino como principio general, según doctrina y jurisprudencia, a todo tipo de obligaciones, como las de hacer o no hacer»: cfr. STS. de 28 de enero de 1998.

${ }^{84}$ Cfr. art. 1189 Cc. Muy razonablemente expresó la STS. de 30 de abril de 1904 que la presunción establecida en este precepto «presupone también, por su naturaleza 
presunción de que todas las obras, siembras y plantaciones han sido hechas por el propietario ${ }^{85}$ a la presunción de la ganancialidad de los bienes existentes en el matrimonio ${ }^{86}$; desde la presunción de igualdad de las porciones de los partícipes en una comunidad de bienes ${ }^{87}$ a las numerosas presunciones posesorias referidas al mantenimiento del título con que se posee, a la justicia de dicho título o a que posee quien tiene su derecho inscrito en el registro de la propiedad, presumida posesión que, a su vez, se presume pública, pacífica, ininterrumpida y de buena $\mathrm{fe}^{88}$. Puede también recordarse aquí la presunción de paternidad del marido del hijo al que su esposa da a luz ${ }^{89}$. Otra presunción legal que supone una verdad oficial, coincidente o no con la realidad histórica o material, es la que afirma la certeza de cuanto -aunque, como puede ocurrir, no se corresponda con la verdad-consta en los libros

de hecho, que el documento a que el mismo se refiere haya estado en algún momento en poder del acreedor, pues de otra suerte no cabría imaginar siquiera la entrega voluntaria».

${ }^{85}$ Cfr. art. 359 Cc. La jurisprudencia suele señalar que el precepto es manifestación de la fuerza expansiva del dominio: cfr., por ejemplo, las STS. de 16 de marzo de 1993 y de 12 de mayo de 1998.

${ }^{86} \mathrm{Cfr}$. art. $1361 \mathrm{Cc}$. Ya puede comprenderse que esta presunción es de gran transcendencia práctica, como demuestra la abundante doctrina jurisprudencial recaída sobre la indicada norma: cfr., entre otras, las STS. de 24 de julio de 1986, de 29 de diciembre de 1987, de 20 de noviembre de 1991, de 23 de diciembre de 1992, de 18 de julio de 1994, de 20 de junio y de 25 de septiembre de 1995, de 8 de marzo y de 2 y de 24 de julio de 1996, de 10 de marzo de 7 de abril, de 14 de julio y de 29 de septiembre de 1997 y de 17 de febrero de 1998. Muchas de estas STS. insisten en que la prevista presunción de ganancialidad requiere, para ser desplazada por la apreciación de privacidad, «prueba expresa y cumplida, no bastando la indiciaria».

${ }^{87}$ Cfr. art. 393 Cc.

${ }^{88}$ Cfr. arts. 436 y 448 Cc. y 35 y 38 Lh. La presunción contenida en el art. 38 Lh. se induce a su vez de la presunción contenida en el anterior art. 35 Lh. desconociéndose así la vieja enseñanza de que praesumptum de praesumpto non admittitur.

${ }^{89}$ Cfr. art. 116 Cc. Esta presunción, como dice la STS. de 11 de febrero de 1987, responde «al conocimiento que transmiten reglas y máximas de experiencia seculares y que resguardan el ámbito de intimidad del matrimonio y su estabilidad familiar» y se justifica por ser la paternidad «un hecho de difícil prueba», en razón de cuya dificultad establece la ley, como dice la STS. de 16 de abril de 1969, «una doble presunción: explícita la relacionada con el tiempo de la concepción, presumiéndose legítimos (ahora matrimoniales) los (hijos) nacidos dentro de cierto plazo (después de la celebración del matrimonio y antes de los trescientos días siguientes a su disolución o a la separación legal o de hecho de los cónyuges); e implícita en orden a la paternidad, presumiéndose que el marido de la madre es padre de los hijos concebidos durante el matrimonio». La STS. de 14 de octubre de 1985 se refiere al «muy rancio abolengo» de la presunción de paternidad de la filiación matrimonial, que arranca de un texto del derecho romano (pater vero is est quem nuptias demostram), que pasó al derecho canónico medieval (qui natus est de uxore alicujus praesumitur filius iustus) y que se recibió luego en la codificación. 
del registro, por estar establecido que «a todos los efectos legales se presumirá que los derechos reales inscritos en el registro existen y pertenecen a su titular en la forma determinada en el asiento respectivo $\rangle^{90}$. En todos estos casos el legislador, siguiendo las reglas que se derivan de la probabilidad basada en la experiencia o de la verosimilitud, deduce plausiblemente que es lo más probable que de unos hechos ciertos y conocidos, por admitidos o probados se sigan otros no conocidos que, en consecuencia de aquéllos, pueden ser presumidos, de manera que respecto de estos hechos presuntos se dispensa de su prueba a la parte litigante a la que la presunción favorece ${ }^{91}$.

Para no abusar de enumeraciones que sería bien fácil ampliar ${ }^{92}$, haré una simple mención de la ideológica "presunción de inocencia», tan importante en el ámbito del derecho penal, así sustantivo como procesal ${ }^{93}$, y me entretendré brevemente en las llamadas presunciones de buena fe, tenidas también frecuentemente en cuenta por el ordenamiento en relación al matrimonio, a la posesión o a la adquisición a non domino ${ }^{94}$.

A diferencia de lo que ocurre en la mayoría de las presunciones legales, cuyo establecimiento por parte del legislador supone, como hemos visto y en correspondencia con el concepto de presunción adoptado por el ordenamiento, una deducción lógica -basada en las ideas de probabilidad ${ }^{95} \mathrm{o}$ de verosimilitud- que infiere de un hecho indicio que es procesalmente cierto, por conocido, probado o admitido, la existencia de un hecho ignorado, la presunción de buena fe no la formula el legislador en función, como establece la propia ley, del «enlace que ha de haber entre el hecho que se presume y el hecho probado o admitido que fundamenta la presunción» ${ }^{96}$, sino que la establece directamente y sin referencia a hecho conocido alguno de que parta una deducción, si bien por plausibles razones de pragmática oportunidad o

${ }^{90}$ Cfr. art. 38 Lh., en su proposición primera.

${ }^{91}$ Cfr. art. 385. 1 Lec.

92 También podrían recordarse la presunción de convivencia de los cónyuges del art. 69 Cc., la presunción de ser medianeros los árboles existentes en un seto vivo medianero del art. 593 Cc., la presunción de no tener el depositario permiso para servirse o usar de la cosa depositada del art. 1768 Cc. o las presunciones de subrogación en la relación obligatoria a que se refiere el art. $1210 \mathrm{Cc}$.

${ }_{93}$ Cfr. art. 24.2, in fine, Const., sobre el que es abundantísima la jurisprudencia, en materia de amparo, del Tribunal Constitucional.

94 Cfr. arts. 79 y 434 Cc. y 34 y 35 Lh.

${ }^{95}$ Como reza, en efecto, un viejo brocardo, praessumptio sumitur de eo quod plerunque fit, máxima a la que se equipara en Francia la de que «la pésomption se tire de ce que arrive le plus souvent»: cfr. Roland-BOYER, Adages du droit français ( $4^{\mathrm{a}}$ ed.), Paris, Litec, 1999, pág. 666. Por su parte, Hedemann, Las presunciones en el derecho cit., pág. 125, habla a propósito de las presunciones de «cristalización de los dogmas de la experiencia».

${ }^{96}$ Cfr. art. 385.3 Lec. 
de seguridad jurídica cuyas implicaciones sería ahora muy largo de explicar. Por tal circunstancia, me ha parecido que a la presunción de buena fe se la puede calificar de irregular, por no ser deducida de un indicio consistente en un hecho previamente considerado cierto o conocido por admitido o probado, frente a la calificación de regulares que conviene a las presunciones, como las anteriormente enumeradas, que se corresponden, en cambio, con el concepto de presunción legal que ha confeccionado el propio legislador ${ }^{97}$.

En razón de poder afirmar las presunciones legales certidumbres sobre hechos que acaso no se corresponden con la realidad, todas ellas -salvo las conocidas como praesumptiones iuris et de iure, de las que luego se hace mención- pueden rebatirse mediante la prueba en contrario. Es por ello por lo que se ha dicho desde antiguo ${ }^{98}$ que las presunciones legales se caracterizan por ser «verdades provisionales ${ }^{99}$, si bien, cuando no se rebaten oportunamente, se convierten, aunque no respondan a la verdad, en «certezas definitivas».

La presunción de un hecho del que no sabe si existe puede ser también indicada -según ocurre en la tradicionalmente llamada praesumptio facti, luego praesumptio hominis o también "presunción simple» y ahora denominada legalmente «presunción judicial»- como establecida por el juzgador, puesto que, «a partir de un hecho admitido o probado», «el tribunal podrá presumir la certeza, a los efectos del proceso, de otro hecho, si entre el admitido o demostrado y el presunto existe un enlace preciso y directo según las reglas del criterio humano» ${ }^{100}$. En relación a esta presunción judicial, cuya base se encuentra en las que pueden llamarse «reglas de la vida» ${ }^{101}$, es claro que, aunque se exija en el juez que su razonamiento sea lógico, no puede de ello derivarse que lo decidido por el juzgador responda realmente a la verdad, aunque, como dice el texto legal, comporte «certeza, a los efectos del proceso». Como se observa con facilidad, también se da aquí por presupuesto, en efecto, que, en derecho, «certeza»y «verdad» no tienen necesariamen-

${ }_{97}$ Me permito remitir, a propósito de estas cuestiones, a Luna SERrano, «El concepto de presunción legal y las denominadas presunciones legales irregulares», en La prueba judicial cit. págs. 213 a 223.

98 De ahí la vieja regula iuris de que probatio vincit praesumptionem o la antigua afirmación doctrinal de que praesumptio cedit veritati, recordaba por DE MAURI, Regulae iuris (11 ${ }^{\mathrm{a}}$ ed.), Milano, Hoepli, 2010 (reimpresión), pág. 182.

99 Así ya las calificaba, por ejemplo, Leibnitz, que de ello justamente concluía que la presunción no es, en sí misma, una prueba, en cuanto que subsiste «jusqu'à ce qu'il est preuve du contraire». «Presumer - precisaba-n'est donc pas prendre avant la preuve, ce qu'il n'est point permis, mais prendre par avance mais avec fondament, en attendant la preuve contraire»: cfr. GiUliani, Leibnitz e la teoria dei fatti relazionali, en Studia prawnicze, 1985, fascs. 3-4 (en honor de Wróbleswski), págs. 39 ss., en donde se recoge el pasaje transcrito en el texto.

${ }^{100}$ Cfr. art. 386.1 Lec.

101 La expresión es de Hedemann, Las presunciones en el derecho cit., pág. 210. 
te que coincidir: por si fuera necesaria una mayor argumentación, obsérvese que es la propia ley la que admite la posibilidad de que la certeza que deriva de la presunción judicial, obtenida mediante una deducción lógica que ha de ser debidamente razonada, no se corresponda con la verdad, en cuanto que permite, aunque no hay acuerdo doctrinal sobre la vía procesal apta para practicarla, la prueba en contrario que destruya dicha presunción ${ }^{102}$.

\subsection{Las verdades presupuestas.}

A veces, el derecho presupone, de manera intuitiva ${ }^{103}$, la existencia de ciertas situaciones y opera en consecuencia como si tales situaciones o circunstancias se hubieran dado en la realidad, otorgándoles la virtualidad de elementos de integración de las previsiones del ordenamiento.

La calificación de estos supuestos de diferenciación entre "certeza»y «verdad» se reporta al concepto de la denominada «presuposición» que se constituiría sobre la «base del negocio» ${ }^{104}$ y que, en cuanto a su posible va-

${ }^{102}$ Cfr. art. 386.2 Lec.

Entre las praesumptiones hominis más características están las que deducen del comportamiento silente de una persona una declaración tácita de la voluntad contractual. Las circunstancias de tal actitud pueden dar lugar, en efecto y mediante una lógica ilación, a presumir que se ha consentido en contratar: cfr. la STS. de 31 de diciembre de 1987, que precisa adecuadamente que «el consentimiento es presunto cuando, no siendo expreso, es meramente probable según las circunstancias», circunstancias que habrían de consistir, naturalmente, en los llamados facta concludentia. Lo derivado de tal conclusión sólo podría tenerse en cuenta por la «vía judicial probatoria para hacerlo aflorar al mundo de la validez y eficacia jurídica, (que) no puede ser otra que la de la presunción»: cfr. STS. de 16 de abril de 1985, que recuerda lo que ya declaró a sensu contrario la STS. de 28 de enero de 1983.

103 Sobre ciertos aspectos relativos a la intuición de la que llama ontología presupuesta, puede verse GRZEGOREZYK, La théorie générale des valeurs et le droit, Paris, L.G.D.J., 1982, obra señalada por PinTORE, Il diritto senza verità cit. págs. 53, n. 20, y 56, n. 26.

${ }^{104} \mathrm{La}$ idea de «presuposición» que campea en el concepto de «implicitud» que se contiene en el art. 1124 Cc. y a la que se refiere en concreto la STS. de 17 de mayo de 1986, en relación a la resolución contractual, se propende hoy a sustituir por las más objetivas de la desaparición de la «base del negocio» o de la frustración del «fin del contrato», según es de ver, a partir de la STS. de 30 de junio de 1948, en las STS., entre otras, de 23 de noviembre de 1962, de 10 de octubre de 1980, de 9 de diciembre de 1983, de 27 de octubre de 1986, de 14 de diciembre de 1993 o de 20 de abril de 1994. Es evidente, sin embargo, que ambos conceptos no son sino versiones relativas a la posición psicológica con que actúan los contratantes, como evidencian las STS. que se refieren a la no obtención de la finalidad perseguida por las partes mediante el contrato y la contradicción que respecto de ella supone la frustración de las legítimas expectativas económicas de quienes pactan o del fin práctico que los contratantes esperan alcanzar: vid., en este sentido, entre otras, las STS. de 18 y de 25 de noviembre de 1983, de 21 de enero de 1984, de 22 de marzo de 1985 o de 11 de julio de 1991.

Sobre estos temas puede verse la contribución de Nicolussi, Presuposizione e risoluzione, en Europa e Diritto privato, 2001-4, págs. 843 ss. 
lencia averiguadora de la voluntad negocial ${ }^{105}$, podría enlazarse con la vieja categoría interpretativa de las conjecturae ${ }^{106}$. Aunque en la actualidad no alcanzan particular relieve en la disciplina normativa ni su concepto suscita excesiva atención doctrinal, no dejan de estar presentes en nuestra legislación ni de recurrir a ellos la jurisprudencia.

En el ámbito legislativo, basta recordar al respecto que el muy importante art. 1124 del Código civil se apoya en una verdad presupuesta cuando afirma que «se entiende implícita en las recíprocas» la facultad de resolver por incumplimiento las obligaciones ${ }^{107}$, precepto que, muy razonablemente, se ampara en la idea, tan sencilla como profunda, de que «no es normal, salvo en situaciones de beneficencia, compasión o caridad, que un ser humano, de natural egoísta, sacrifique una parte de su patrimonio, o asuma una carga obligacional, y se avenga a empobrecerse en beneficio de otro sin justificación alguna, sin recibir algo que para él valga más, o lo prefiera a lo que sacrifica», pues es claro que «nadie se sacrifica sino es por causa de que va a recibir la contrapartida», de modo que, si tal habitual creencia actúa subjetivamente, ella «objetivamente exige que la contrapartida sea real» ${ }^{108}$.

${ }^{105}$ La teoría de la presuposición puede, en efecto, presentarse con un perfil interpretativo en orden a la averiguación del contenido de la voluntad negocial. Tal concepción doctrinal podría permitir al intérprete, sin caer en los excesos del psicologismo, individualizar el verdadero contenido de la voluntad declarada, «a través de la comprobación de las circunstancias en que se desarrolla el procedimiento contractual, y de su verdadero objeto, así como alcanzar no únicamente la auténtica intención de los autores del negocio o causa impulsiva, sino también su fundamento ético (causa materialis) protegida por la ley en la causa finalis»: cfr. PALAzzo, Etica del diritto privato (obra que también contiene escritos de Ferranti), I, Padova, Cedam, 2002, pág. 91.

106 En la doctrina de nuestros clásicos es habitual colocar en el ámbito de las conjeturas la señalada en el texto como cláusula rebus sic stantibus: cfr. CASTILlo DE SOTOMAYOR, De conjecturis, IV, 59, núms. 11 ss., págs. 604 ss.

Por su parte, y aunque amparada bajo el rótulo de presunción, se acerca más al concepto de presuposición la clásica «conjetura de piedad» que tradicionalmente ha señalado, en el derecho sucesorio catalán, que, si se impone expresa o tácitamente al hijo o descendiente del fideicomitente la substitución fideicomisaria a favor de persona que no cumple dicha condición, se habrá de entender - «por conjetura de piedad»- que el fideicomiso se dispuso bajo la condición de que muriese el fiduciario sin dejar hijos o descendientes: cfr. art. 191 del Código de sucesiones por causa de muerte en el derecho civil de Cataluña, aprobado por la ley 40/1998, de 30 de diciembre, si bien la referencia a dicha conjetura se ha suprimido ahora en el art. 426-15 del libro IV del Código civil de Cataluña, aprobado por ley 10/2008 de 10 de julio.

${ }^{107}$ La STS. de 21 de febrero de 1990 refiere básicamente la resolución contractual al juego de la presupuesta cláusula rebus sic stantibus.

108 Tomo estas expresiones de un texto inédito - espléndido como suyo- de PINTó Ruíz, Estudio sobre el art. 1.124 del Códico civil, constitutivo de una ponencia presentada en la Real Academia de Jurisprudencia y Legislación (curso 2010-2011), cuyo envío 
Por lo demás, y aunque en estos supuestos no se haga referencia a ninguna cláusula condicional implícita, es también de considerar que la idea de la presuposición se encuentra en la base de las normas que, frente al principio general de irrevocabilidad de las donaciones, previenen excepcionalmente la revocación, a iniciativa del donante, de las mismas y que se contienen en los arts. 644 y 648 del Código civil ${ }^{109}$.

Por su parte, la jurisprudencia, aunque con continuas llamadas de atención a la cautela y a la prudencia, no deja de acudir, recordando a veces la teoría de la presuposición o de la base del negocio ${ }^{110}$, a una hipotética y presupuesta condición tácita o «no desarrollada» y, en concreto, a una «implícita cláusula rebus sic stantibus et aliquo de novo non emergentibus» en orden a corregir, a través de una suerte de reductio ad equitatem, los sobrevenidos e imprevisibles desequilibrios que se producen, con carácter grave, en las relaciones contractuales ${ }^{111}$.

\subsection{Las verdades aparentes.}

Mayor interés pueden suscitar las verdades aparentes, frecuentemente tenidas en cuenta por el derecho con el fin de establecer «certeza» por par-

mucho agradezco. Con ideas que con las expuestas se corresponden, explica TRIMARCHI, Istituzioni di diritto civile (2 $2^{\mathrm{a}}$ ed.), Milano, Giuffrè, 1975, pág. 347, que «se habla de presuposición cuando existe un motivo conocido por ambas partes y que es el determinante para justificar económicamente el contrato, como, por ejemplo, la compra de un terreno para construir un hotel que luego no tiene la oportuna licencia».

Entre las diversas contribuciones sobre el precepto citado en el texto pueden verse las de Jordano Barea, Cumplimiento tardio y facultad resolutroria tácita, en Anuario de Derecho Civil, 1951, págs. 307 ss.; Álvarez VigaraY, La resolución de los contratos bilaterales por incumplimiento, Granada, Comares, 2003; Clemente Meoro, La resolución de los contratos por incumplimiento, Valencia, Tirant lo Blanch, 1992, Dell'AcQuila, La resolución del contrato bilateral por incumplimiento, Salamanca, 1981; GonzÁLEZ GonzÁlez, La resolución como efecto del incumpliendo en las obligaciones bilaterales, Barcelona, J.M. Bosch, 1987; VerderA, Inadempimento e risoluzione del contratto, Padova, Cedam, 1994; HAzA, El incumpliendo resolutorio. Análisis de la jurisprudencia del Tribunal Supremo, Madrid, 1996; y Diez PicAzo, Los incumplimientos resolutorios, Madrid, Thomson-Civitas, 2005.

109 En relación al supuesto concreto de la revocación de las donaciones por ingratitud del art. 648 Cc., la STS. de 29 de noviembre de 1969, se refiere a un psicológico ius gratitudinis que asistiría al donante y a los correlativos «deberes morales» de agradecimiento que recaerían sobre el donatario. Cfr., sobre la excepcionalidad indicada en el texto la STS. de 21 de mayo de 1984.

${ }^{110}$ Cfr., por ejemplo, las STS. de 17 de mayo de 1986, de 21 de febrero y 10 de noviembre de 1990 y de 6 de noviembre de 1992.

111 Sobre el aprovechamiento de esta categoría - de elaboración doctrinal- por el Tribunal Supremo con la finalidad indicada en el texto, vid., por todas sus resoluciones y en razón de su expresividad, la STS. de 23 de abril de 1991, que resume y sistematiza 
te del ordenamiento, que, como es bien sabido, suele tener muy en cuenta el statu quo y, en consecuencia con ello, las apariencias. En el caso de las verdades aparentes es indudable, como vamos a ver, que el derecho se fija atentamente en la realidad, pero es igualmente cierto que «prefiere la realidad superficial a la profunda realidad ${ }^{112}$, es decir, que se contenta con lo que «aparece»y, por razones de utilidad que reclama la organización de la vida social, sin exigirse la averiguación de lo que realmente «es».

Es indudable, como ha puesto de relieve nuestra mejor doctrina, la apariencia de titularidad de las cosas que se desprende de su posesión, en particular de la posesión que se disfruta en los bienes muebles. El ejemplo más significativo de la virtualidad de la apariencia de propiedad que se desprende de la posesión es la figura de la adquisición a non domino a que se refiere el tan estudiado por la doctrina art. 464 del Código civil, a tenor del cual y siguiendo la vieja regla originada en el derecho consuetudinario francés de que «en fait de meubles possession vaut titre», recogida literalmente en el art. 2279 del Código de Napoleón, se dispone que «la posesión de los bienes muebles adquiridos de buena fe equivale al título», precepto que es mayoritariamente entendido en el sentido de que el título a que se refiere la norma es el título de propiedad ${ }^{113}$. También en razón de la virtualidad de la apariencia dispone el artículo 85 de Código de comercio que «la compra de mercaderías en almacenes o tiendas abiertos al público causará prescripción de derecho a favor del comprador», aunque el vendedor no sea propietario,

la jurisprudencia anterior y cuya doctrina se ha trasladado a otras sentencias posteriores, como, por ejemplo, las STS. de 6 de noviembre de 1992, de 29 de mayo y de 10 de junio de 1996 y de 10 de febrero de 1997.

Son de recordar sobre esta cuestión las contribuciones de BADENES GASSET, El riesgo imprevisible, Barcelona, Bosch, 1946; de CANDIL, La cláusula «rebus sic stantibus» ( $2^{\mathrm{a}}$ ed.), Madrid, 1946; de AtTARD Alonso, En torno a la cláusula «rebus sic stantibus», Valencia, 1951; de Terraza MARTORELl, Modificación y resolución de los contratos por excesiva onerosidad, Barcelona, Bosch, 1953; de Arrechederra Aranzadi, La equivalencia de las prestaciones en el derecho contractual, Madrid, 1978; de GaVIRIA, Presuposición y riesgo contractual, en Anuario de Derecho Civil, 1987-2, págs. 525 ss.; de DE Amunategui Rodríguez, La cláusula «rebus sic stantibus», Valencia, Tirant lo Blanch, 2003; y de Martínez Velencoso, La alteración de las circunstancias contractuales, Madrid, Cívitas, 2003. En la doctrina italiana es clásica la obra de PINO, L'eccessiva onerosità della prestazione, Padova, Cedam, 1952.

112 Cfr. Louss-Lucas, Verité matérielle et verité juridique cit., pág. 593.

113 Que se trate propiamente de título de propiedad -dándose lugar, por tanto, a una adquisición a non domino- no deja de tener contradictores en nuestra doctrina, pero la opinión indicada en el texto -que acoge la llamada interpretación «germanista» del precepto-, aparte de obtener amplio sufragio científico, es también seguida con frecuencia por la jurisprudencia: vid., por ejemplo, entre otras, las STS. de 3 de marzo de 1980, de 26 de junio de 1984, de 15 de febrero de 1990 y de 25 de febrero de 1992. 
sino mero tenedor, de las mismas ${ }^{114}$. La idea de protección de la apariencia subyace también a la consideración de la creencia de que el contenido en los asientos registrales se corresponde con la verdad que se deriva de la realidad y de que, en tal sentido, suministra a quien consulta el registro de la propiedad una certeza que cuando sirve de base a una decisión que se toma en función de ella no se puede defraudar: en virtud del art. 34 de la ley hipotecaria, en efecto, quien adquiere de buena fe un inmueble de quien, según el registro, se lo puede transmitir y paga por dicha adquisición e inscribe la misma «será mantenido en su adquisición» ${ }^{115}$. Piénsese asimismo en la trascendencia del llamado «signo aparente» de la servidumbre, que determina, de una parte, que no se pueda alegar desconocimiento de la existencia del gravamen cuando se adquiere la finca sirviente sin que aquél conste en los libros del registro -al tener la apariencia que se desprende del signo tanto o más valor que la publicidad registral ${ }^{116}-\mathrm{y}$, de otra, que, si el signo no se destruye o se le priva de relevancia, puede dar lugar al supuesto de la llamada constitución de servidumbre por destino del padre de familia ${ }^{117}$.

Por lo demás, con el hecho de poseer se conectan o derivan otras numerosas presunciones legales, a las cuales se ha hecho referencia con anterioridad.

Debe hacerse también referencia aquí a los supuestos del valor de la apariencia de la llamada posesión de estado -cifrada por los clásicos en el nomen, el tractatus o la fama- respecto de la reclamación de la filiación o de la que se entraña en la figura mercantil del «factor notorio» ${ }^{118}$,

114 Véase también el art. 195 Ccom., según el cual «el poseedor de los resguardos (expedidos por las compañías de almacenes generales de depósito, conocidos como «warrants») tendrá pleno dominio sobre los efectos depositados».

115 Sobre los temas indicados en el texto puede verse la interesante contribución de De Ángel YagüEz, Apariencia jurídica, posesión y publicidad inmobiliaria registral, Bilbao, Universidad de Deusto, 1975.

116 Véanse, en tal sentido, entre otras muchas, las STS. de 25 de febrero de 1956, de 27 de junio y de 23 de octubre de 1980, de 15 de marzo de 1993, de 23 de marzo de 2001 y de 2 de diciembre de 2002 .

117 Cfr. art. 541 Cc. Sobre el tema pueden verse Bonet Correa, La constitución de servidumbre por signo aparente. La «destinación del padre de familia», Madrid, C.S.I.C., 1970, y Llácer MatacÁs, El título constitutivo en el art. 541 del Código civil, Barcelona, Bosch, 1996.

118 A la figura del factor notorio se refiere el art. 286 Ccom., según el cual -y en base a la apariencia- la actividad de dicho factor vincula al empresario cuando aquélla se desenvuelve en el ámbito del «giro y tráfico del establecimiento». Como declara una doctrina jurisprudencial muy consolidada, la actividad de dicho «factor» crea la apariencia de estar contratando con un verdadero apoderado: cfr., en tal sentido, entre otras muchas, las STS. de 30 de septiembre de 1960, de 22 de junio de 1989, de 14 de mayo de 1991, de 13 de mayo de 1992, de 18 de noviembre de 1996, de 31 de marzo de 1998, de 27 de diciembre de 1999. de 2 de abril de 2004, de 7 de noviembre de 2005, de 6 de marzo de 2006 y de 27 de marzo y de 28 de septiembre de 2007. 
en la figura administrativa del «funcionario de hecho»-que, sin nombramiento legal, ejerce aparentemente funciones públicas ${ }^{119}$ - o en la figura del juez, alcalde o funcionario incompetente o falto de legítimo nombramiento que no se presenta como tal, sino que ejerce sus funciones públicamente, y autoriza un matrimonio civil ${ }^{120}$. En cierto modo, se comunica aquí y subyace en todos estos casos la idea de la transcendencia aparencial de la posesión de los bienes, categoría conceptual a semejanza de la cual, como ya demuestra la indicada referencia a la posesión de estado, se han configurado los otros supuestos de consideración de la apariencia por parte del legislador. En este sentido, alcanza especial relieve en el derecho la figura de la posesión del crédito, en el sentido de que el pago hecho al acreedor aparente, que aunque sin serlo es apreciado socialmente como tal, «liberará -como dice el art. 1164 del Código civil-al deudor» ${ }^{121}$. Juntamente con la figura del acreedor aparente alcanzan también especial relieve en la práctica la figura del propietario aparente ${ }^{122}$,

119 En este sentido, por ejemplo, se considerarían válidos los actos llevados a cabo por un funcionario cuyo nombramiento como tal fuera nulo y antes de declararse su nulidad. Sobre esta figura puede verse la contribución de FLISFISCH BRONSTEIN, El funcionario de hecho, Santiago de Chile, Editorial Jurídica de Chile, 1968 (un vol. de 117 págs.).

${ }^{120}$ Cfr. art. 53 Cc.

${ }^{121}$ De la figura del acreedor aparente se ha ocupado con frecuencia la jurisprudencia: cfr., entre otras, las STS. de 4 de julio de 1944, de 12 de junio de 1953, de 22 de febrero de 1988 , de 30 de octubre de 1995 y de 17 de octubre de 1998, la última de las cuales explica acertadamente que el precepto indicado «implica protección de la confianza en la apariencia jurídica», lo que requiere que quien se presenta y actúa como acreedor lo haga con una apariencia adecuada, razonable, objetivamente verosímil», en cuanto que «sólo la razonabilidad de la legitimación aparente justifica la liberación del deudor».

No se crea que la figura del acreedor aparente no se da en la realidad, en particular en el caso de que se revista tal conceptuación social en función de ser una persona heredero aparente. No hace muchos años conocí el caso de una persona que se cuidó durante muchos años de la administración del patrimonio mobiliario y de los pagos que comportaba la atención de un tío suyo, de manera que, cuando murió éste, creyó de buena fe dicho sobrino, así como los hermanos del fallecido, que aquél era su heredero. Dicho sobrino y aparente heredero, muy conocido en la oficina de una entidad bancaria como gestor de los valores mobiliarios depositados en ella, siguió manejando tales depósitos, en calidad, creída por todos, de heredero. Al cambiar el director de dicha oficina bancaria y no conocerle el sustituto, éste pidió al aparente sucesor que documentase su cualidad de heredero. Con gran sorpresa de éste y de sus otros tíos, el fallecido no había otorgado testamento, por lo que le sucedieron $a b$ intestato y como parientes más cercanos del de cuius sus hermanos y tíos del que fue durante bastante tiempo su «heredero aparente».

${ }^{122}$ En relación a la venta de una cosa ajena cuya figura se contempla en el art. 1599 del Código de Napoleón, la jurisprudencia francesa suele hablar del «propriétaire apparent» y del «propriétaire véritable»: cfr., por ejemplo, la S. de 22 de julio 
la del heredero aparente ${ }^{123}$, la del mandatario aparente ${ }^{124} \mathrm{o}$ también la de la llamada sociedad irregular o de hecho, que, a ciertos efectos, se tiene por constituida en cuanto basada en una agrupación de personas que reúne todas las condiciones que serían necesarias para su plena existencia jurídica pero que no ha conseguido adquirir el necesario marchamo constitutivo previsto legalmente ${ }^{125}$.

En todos los casos indicados, en que hay un defecto de derecho o un defecto de poder, la apariencia es fuente de una creencia errónea derivada de una situación de hecho, que es fruto de un déficit de información y que el ordenamiento no deja de considerar -se ha hablado a esto propósito en la doctrina francesa de una «apparence légalisée» ${ }^{126}$ - si el que se fía de dicha apariencia opera consecuentemente, es decir, con «creencia legítima» o de buena fe.

Dado que el fundamento de la protección de la apariencia se basa en un déficit de información, la categoría de las «verdades aparentes», en función de las cuales se orientan las conductas, alcanza en la actualidad un especial interés en materia de contratación con los consumidores y ello en el doble sentido -y al margen de los deberes de información, que son propios de todo contratante, pero que tienen una particular incidencia en tal suerte de

de 1986, en Bulletin des arrêts des Chambres civiles de la Cour de Cassation, 1986, I, nº 214, pág. 205.

Sobre la venta de cosa ajena pueden verse, entre otros, Rodríguez Morata, Venta de cosa ajena y evicción, Barcelona, J. M. Bosch, 1990, y Fernández De Villavicencio Álvarez-Ossorio, Compraventa de cosa ajena, Barcelona, J. M. Bosch, 1994.

${ }^{123}$ Véase, sobre este punto, Jordano BAREA, La teoría del heredero aparente y la protección de los terceros, en Anuario de Derecho Civil, 1950, págs. 668 ss. y FernánDEZ ARRoyo, La acción de petición de herencia y el heredero aparente, Barcelona, J. M. Bosch, 1994.

${ }^{124}$ La protección del tercero que adquiere del mandatario aparente es referida, en efecto, por la STS. de 3 de julio de 1976, a «una especie de protección de la confianza en la apariencia frente a la realidad jurídica».

Sobre el mandatario aparente puede verse la contribución de Gordillo CAÑAS, La representación aparente. Una aplicación del principio general de protección de la apariencia jurídica, Sevilla, Publicaciones de la Universidad, 1978.

${ }^{125}$ En las relaciones de la «sociedad» con los terceros habría de tenerse en cuenta la apariencia de sociedad que hubiera generado la confianza de dichos terceros. En este sentido, parece que la falta de personalidad jurídica de dicha sociedad no podría aducirse, para beneficiarse mediante la alegación del art. 1669 Cc., por los «socios», pudiendo los terceros que contrataron con la aparente sociedad alegar dicho precepto frente a los «socios» en defensa de sus intereses: véanse al respecto las STS. de 30 de abril de 1983 y de 17 de septiembre de 1984. Sobre la figura considerada puede verse VALPUESTA GASTAMINZA, La sociedad irregular, Pamplona, Aranzadi, 1995.

126 Tomo esta expresión de DANIS-FAnTÔME, Apparence et contrat cit., págs. 77 a 87. 
contratación- de que, por una parte, la legislación de defensa de los consumidores suele otorgar fuerza obligatoria al contenido aparente del contrato, cuando es insuficiente la información, y de que, por otra parte, se da en ella transcendencia, para integrar el contenido del contrato, a los documentos publicitarios. En este sentido, el art. 61.2 del texto refundido de la ley general para la defensa de consumidores y usuarios, aprobado por el Real Decreto Legislativo 1/2007, de 16 de noviembre, establece que, tanto las «prestaciones propias de cada bien o servicio» como el «contenido de la oferta, promoción o publicidad» y las «condiciones jurídicas o económicas y garantías ofrecidas», «serán exigibles por los consumidores y usuarios, aún cuando no figuren expresamente en el contrato celebrado o en el documento o comprobante recibido y deberán tenerse en cuenta en la determinación del principio de conformidad del contrato» ${ }^{127}$

El indicio de verdad que reside en la apariencia es, por lo demás, tan relevante para el derecho que sobre su base se asientan y formulan tanto el principio general de tutela de la confianza como el también principio general, que no es sino reverso del anterior, de la autoresponsabilidad, de los que ambos se aprovecha en sus resoluciones nuestra jurisprudencia ${ }^{128}$.

A la protección de la confianza que se basa en la conducta exteriorizada por una persona se ordena también el -tantas veces aprovechado por la

${ }^{127}$ Por su parte, y en específica relación al «programa o folleto informativo» que contenga la oferta sobre el viaje combinado, la misma determina que su contenido tiene carácter vinculante para el organizador y el detallista de dicho viaje: cfr. arts. 152 y 153 del texto refundido de la ley general para la defensa de consumidores y usuarios.

En relación a la venta de viviendas, la jurisprudencia ha atendido en diversas ocasiones al valor de la propaganda relativa a las mismas en orden a la integración del contrato. Así, por ejemplo, la STS. de 27 de enero de 1977, con doctrina que se reitera en las STS. de 9 de febrero de 1981, 7 de noviembre de 1988, 20 de enero de 1989, 21 de julio de 1993 y de 8 de noviembre de 1996, declara que, «siendo muy parco el contrato privado suscrito por las partes en elementos descriptivos, es lógico, como dice la instancia, que el adquirente del piso se atenga a lo prometido en los folletos de propaganda, de acuerdo con el principio de buena fe proclamado en el art. $1258 \mathrm{Cc}$., al creerlos, con todo fundamento, vinculantes para la empresa».

128 Véase a este propósito, por ejemplo, la STS. de 16 de noviembre de 1979, que declara que «en toda relación jurídica, en su revelación objetiva que es la esencia indagadora de la voluntad reflejada en el consentimiento, lo fundamental a proteger es la confianza, ya que el no hacerlo es atacar a la buena fe, que ciertamente viene determinada por una coherencia de comportamiento en las relaciones humanas y negociales, toda vez que cuando unas determinadas personas, dentro de un convenio jurídico, han suscitado con su conducta contractual una confianza mutua fundada, conforme a la buena fe, en una determinada conducta, no deben defraudar esa confianza suscitada, y es inadmisible toda actuación incompatible con ella, por la sencilla razón de que, como ya viene dicho, la exigencia jurídica del comportamiento coherente está vinculada de manera estrecha a la buena fe y a la protección de la confianza». 
jurisprudencia ${ }^{129}$ - llamado principio general de non venire contra factum proprium, que se ordena a la exigencia de que la conducta observada por un sujeto sea coherente, de manera que los actos que realiza y que son percibidos por los demás no pueden ser modificados en perjuicio de quienes han puesto su confianza en lo que dichos actos significan.

\subsection{Las verdades simuladas.}

Otros supuestos de verdades oficiales consisten en las verdades simuladas, que son verdades putativas cuya credibilidad radica en la verosimilitud de mezclar la exteriorización de lo falso con la ocultación de lo verdade$\mathrm{ro}^{130}$. admitidas en nuestro ordenamiento a propósito de la contratación, en el ámbito de la cual la simulación llamada relativa es admitida sin ninguna dificultad ${ }^{131}$.

La simulación relativa es la que tiene lugar, con bastante frecuencia, cuando se dice celebrar un contrato (contrato simulado) cuando en realidad se quiere celebrar otro (contrato disimulado), tanto en el sentido de concluir efectivamente un contrato pero manifestar que se hace otro -por ejemplo, según es muy usual, una donación que se enmascara de compraventa ${ }^{132}-$,

${ }^{129}$ La jurisprudencia sobre la doctrina de los «actos propios» - a la que también hace referencia la STS. citada en la $n$. anterior- es muy abundante, pudiendo representarse su doctrina por la muy expresiva STS. de 16 de febrero de 1998. Véase, a este propósito, Diez-Picazo, La doctrina de los actos propios. Un estudio crítico de la jurisprudencia del Tribunal Supremo, Barcelona, Bosch, 1965.

${ }^{130}$ La verdad simulada es atendida por el derecho en gracia precisamente de su verosimilitud mientras no se comprueba la existencia de la simulación. Viene a cuento a este propósito la sensata reflexión, de visos pirandellianos, de que «nella vita ci sono cose vere poco verosimili e cose false molto verosimili, ad esempio quelle fabbricate a bella posta in un giuoco di simulazione del vero e dissimulazione del falso che serve a coprire la realtà dei fatti come sono accaduti»: cfr., Gotor, Il memoriale della repubblica cit., pág. 218.

131 Sobre la simulación puede verse, en nuestra doctrina reciente, CÁrCABA, La simulación en los negocios jurídicos, Barcelona, J. M. Bosch, 1986, y Durán RIVAcoBA, Donación de inmuebles. Forma y simulación, Pamplona, Aranzadi, 1995. Véase también Salvador Coderch y Silva SÁnchez, Simulación y deberes de veracidad: derecho civil y derecho penal. Dos estudios de dogmática jurídica, Madrid, Cívitas, 1995.

En la doctrina italiana, son clásicas las obras de Ferrara, Della simulazione dei negozi giuridici, Roma, 1922, de cuya quinta ed. existe trad. esp. a cargo de Atard y De la Fuente (Madrid, Revista de Derecho Privado, 1931, $2^{\text {a }}$ ed.) y de Auricchio, La simulazione del negozio giuridico. Premesse generali, Napoli, Jovene, 1957. Más recientemente pueden verse GentiLI, Il contratto simulato (teorie della simulazione e analisi del linguaggio, Napoli, Jovene, 1982; NuTI, La simulazione del contratto nel sistema del diritto civile, Milano, Giuffrè, 1986; y FurgIUele, Della simulazione di effetti negoziali, Padova, Cedam, 1992.

${ }^{132}$ La abundancia de decisiones jurisprudenciales sobre este supuesto - cuya doctrina 
como en el de consignar en el documento en el que el contrato consta una fecha distinta de la real, en el de hacer figurar en dicho documento condiciones, plazos o términos que no se quieren o en el de señalar en el mismo un precio de venta diferente del efectivamente querido y satisfecho. En estos casos de simulación relativa decían los antiguos que el contrato colorem habet, substantiam vero alteram, en cuanto que está «destinado a ocultar otro contrato diferente, que es el verdaderamente querido por las partes $\rangle^{133}$, de manera que, por eso, debía valer, siempre que pueda probarse su conclusión ${ }^{134}$, el contrato disimulado, careciendo de transcendencia el disfraz del mismo en que consiste el contrato simulado ${ }^{135}$, si bien este contrato, en cuanto exteriorizado, seguiría, en principio, apareciendo como verdadero -en decir, como cierto- respecto de terceras personas.

También podría ocurrir que se simule celebrar un contrato cuando en realidad no se quiere celebrar ninguno, en cuyo caso, que configura la llamada simulación absoluta, habría de decirse que el contrato colorem habet, substantiam vero nullam, por lo cual no se daría ningún efecto a lo realizado por los simulados contratantes ${ }^{136}$. En este caso, desde luego, como «las par-

«ha sido muy fluctuante en cuanto a la aceptación de las donaciones encubiertas bajo la forma de compraventa», según reconoce la STS. de 14 de marzo de 1995- es buena prueba de la frecuente práctica de esta suerte de simulación: pueden citarse al respecto, entre otras muchas, las STS. de 19 de noviembre de 1987, de 9 de mayo de 1988, de 22 de enero de 1991 y de 14 de marzo y de 30 de septiembre de 1995.

133 Sigo aquí expresiones del gran civilista barcelonés Puig Brutau, Fundamentos de derecho civil, II, 1 (Doctrina general del contrato) (2 ${ }^{\mathrm{a}}$ ed.), Barcelona, Casa Editorial Bosch, 1978, pág. 487.

${ }^{134}$ La jurisprudencia insiste en la frecuente dificultad de la prueba directa de la existencia del contrato válido, oculto o disimulado, así como en el hecho de haber de recurrirse no pocas veces a «indicios con fortaleza suficiente»: cfr. STS. de 13 de octubre de 1993, haciendo referencia en muchas ocasiones a las presunciones: cfr., entre otras, STS. de 2 de diciembre de 1983, de 10 de julio de 1984, de 16 de septiembre de 1991, de 15 de noviembre de 1993 y de 14 de junio de 1997. De ahí que los simulantes suelan proveerse de una «contradeclaración» escrita de la celebración del contrato disimulado, preconstituyendo la prueba del mismo.

135 Doctrina y jurisprudencia con rara unanimidad refieren la disciplina de la simulación contractual al art. $1276 \mathrm{Cc}$., alegando que se refiere a la «expresión de una causa falsa en los contratos» que puede estar «fundada en otra verdadera y lícita». Sin embargo esta postura puede rebatirse alegando, de una parte, que la falsedad de la causa indicada en el precepto no puede ser otra -a nos ser que el legislador utilice las mismas palabras para aludir a dos cosas distintas- que el error que mueve al autor del negocio (cfr. arts. 767 y 1301.2 Cc.) y, de otra, que si se tuviera en cuenta el precepto se reduciría a la causa el ámbito potencial de la simulación, que alcanza frecuentemente, en cambio, a la fecha del negocio y a los términos y condiciones incluidas en el mismo.

${ }^{136}$ Es apenas el caso de consignar aquí que carece de toda validez el matrimonio simulado, del que no faltan ejemplos en la actualidad, por la simple razón de que en el 
tes están de acuerdo en que el contrato no existe a pesar de su apariencia», lo que quieren es que «detrás de tal apariencia subsista la realidad jurídica anterior» ${ }^{137}$.

En el campo de la simulación cabe también situar la que, en el ámbito procesal relativo a la prueba, se puede llamar «verdad negociada» y que tiene lugar cuando frente a la alegación de un hecho por el actor se conviene con el demandado que no formule oposición, de modo que, en consecuencia, tal hecho alcance la consideración de «hecho pacífico»y, en función de tal calificación, sea tenido en cuenta por el juez ${ }^{138}$.

\subsection{Las verdades fiduciarias.}

Cercanas a las verdades simuladas, en cuanto que el contrato simulado es a veces el vehículo del fiduciario, son aquellas que resultan de la celebración de un contrato para el que, en base a la relación de confianza o causa fiduciae que existe entre los interesados, se quiere un efecto distinto, más tenue o más limitado, del efecto más intenso que corresponde al tipo contractual utilizado, efecto éste que es el que, aunque no querido ni por tanto «verdadero», aparece al exterior y, por tanto, se tiene oficialmente por «cierto».

Estos supuestos de verdades fiduciarias que lo son únicamente en cuanto queridos por los contratantes que confían entre ellos, no están contemplados expresamente en nuestra legislación, pero se han presentado siempre en las relaciones entre particulares, aparecen continuamente en la vida social -con particular incidencia en el ámbito mercantil ${ }^{139}-\mathrm{y}$, desde luego, son admitidos, siempre que con ellos no se incurra en fraude, por la jurisprudencia, particularmente copiosa en tema de relaciones jurídicas fiduciarias ${ }^{140}$.

mismo falta el indispensable consentimiento matrimonial, sin el cual, como tajantemente expresa el art. $45 \mathrm{Cc}$., «no hay matrimonio».

137 Continúo aquí aprovechando expresiones de Puig Brutau, Fundamentos de derecho civil cit., págs. 58 y 487.

138 Sobre este punto, véase TARUfFo, Simplemente la verdad cit., págs. 140 a 153, que sugiere que en tal caso, por darse lugar a un déficit del descubrimiento de la verdad, se puede hablar de «verdad incompleta». Es evidente que la falta de oposición también puede deberse a la inadvertencia del demandado, pero en este caso podría asimismo hablarse, en relación al hecho que resulta pacífico, de una verdad considerada tal aunque no se haya contradicho.

Es evidente que la simulación en relación al proceso podría ir a más. En la experiencia jurídica romana eran conocidos los procesos simulados y no es del todo descartable que se den en la realidad procedimiento arbitrales o jurisdiccionales que adolezcan de semejante anomalía.

139 Vid., a este propósito, Garrigues Díaz-Cañabate, Negocios fiduciarios en el derecho mercantil, Madrid, Cívitas, 1978, con ed. anterior de 1955.

${ }^{140}$ La STS. de 2 de diciembre de 1996 ha descrito la contratación fiduciaria declarando que «el negocio fiduciario consiste en la atribución patrimonial que uno de los 
Los ejemplos que se cuentan en la experiencia suelen agruparse, por común referencia a una causa fiduciae en la que se vierte la confianza que une a los contratantes, bajo las denominaciones de fiducia cum amico y de fiducia cum creditore. Al primer tipo de fiducia se adscribe el contrato, bastante corriente, por el que un bien - una cosa o un derecho- se transmite, se adjudica o se pone a nombre de otra persona, distinta a la de quien, sin embargo, quiere continuar siendo verdadero titular o propietario: por ejemplo, y para formar una sola finca con las dos que pertenecen a dos socios, vendiendo uno al otro la suya para facilitar así la obtención de un único y más cuantioso préstamo hipotecario ${ }^{141}$; o atribuyendo al adjudicatario de ciertos bienes en la división de una herencia no para que los reciba y se los quede sino para que los aplique al pago de las deudas hereditarias; o bien cediendo una persona sus bienes a otra para aparecer como menos pudiente; o, incluso, como a veces ha ocurrido, para sortear el riesgo de una eventual incautación de bienes ${ }^{142}$.

El caso de la llamada fiducia cum creditore es más interesante y también más usual. Se da en la llamada "venta en garantía», que se concierta, para tener la seguridad de evitar el riesgo de que el dinero que en realidad se presta no se devuelva, configurando a dicha cantidad prestada como precio de compra de un bien que se entrega a quien en verdad es prestamista con pacto de retrocesión del bien al prestatario en el momento de la devolución de la cantidad objeto del préstamo. De esta manera, y con la indicada finalidad de garantía, se hace aparecer a quien pide dinero como vendedor y a quien lo presta como comprador del bien. Es precisamente para alejar el supuesto de la tacha de ser el contrato descrito contrario a la prohibición del pacto comi-

contratantes, llamado fiduciante, realiza a favor de otro, llamado fiduciario, para que éste utilice la cosa o el derecho adquirido, mediante la referida asignación, para la finalidad que ambos pactaron, con la obligación de retransmitirlos al fiduciante o a un tercero cuando se hubiera cumplido la finalidad propuesta»; de modo que, "cuando no envuelve fraude de ley, el contrato explicado es válido».

Al negocio fiduciario han prestado especial atención, entre nosotros, De CASTRo, El negocio jurídico, Madrid, Instituto Nacional de Estudios Jurídicos, 1967, págs. 379 a 442 , que ha dedicado al asunto otros trabajos anteriores, y JordANo BAREA, El negocio fiduciario, Barcelona, 1958, que también se ha ocupado de este punto en otras contribuciones. Véase también, más recientemente, FuENTESECA (C.), El negocio fiduciario en la jurisprudencia del Tribunal Supremo, Barcelona, J. M. Bosch, 1997. En la doctrina italiana destacan los estudios de CAriota-Ferrara, I negozi fiduciari, Padova, Cedam, 1933 y, más modernamente, de Lipari, Il negozio fiduciario, Milano, Giuffrè, 1964.

141 Este caso fue examinado en la STS. de 2 de diciembre de 1983.

${ }^{142}$ A este último supuesto hicieron referencia, en cuanto a cesiones hechas durante la guerra civil por entidades eclesiásticas, las leyes de 11 de julio de 1941 y de 1 de enero de 1942 y en cuanto a cesiones hechas en dicha época por cualquier persona, el DecretoLey de 28 de junio de 1962. 
sorio o de incurrir en prácticas usurarias, por lo que suele, en efecto, acompañarse la «venta» con la concesión a favor del «vendedor» y en realidad prestatario de un derecho de recompra o de retracto convencional a ejercitar en el momento del vencimiento y abono de la deuda ${ }^{143}$.

En definitiva, se da en estos supuestos la atribución patrimonial que uno de los contratantes, llamado fiduciante, realiza a favor de otro, llamado fiduciario, para que éste utilice la cosa o derecho adquirido para la finalidad que ambos pactaron, con la obligación de retransmitirlos al fiduciante o a un tercero cuando se hubiere cumplido la finalidad prevista ${ }^{144}$.

Como se ve, en todos los casos indicados se advierte, de una parte, una propiedad verdadera o material y, de otra, una propiedad fiduciaria o formal, de manera que, no obstante la diversa «verdad» que subyace en el supuesto, es la titularidad fiduciaria la que, hacia el exterior, alcanza oficialmente «certeza».

\subsection{Las verdades ficticias.}

Se ha llegado a decir, en alguna ocasión, que el derecho es un saber sobre la ficción, en cuanto que traduce la estructura en norma, o bien un saber sobre esta transformación y, por inmediata consecuencia, un saber sobre la palabra ${ }^{145}$, y también que debe entenderse ahora desde esta perspectiva la vieja imagen medieval de que la fictio (est) figura veritatis ${ }^{146}$. En todo caso, en cuanto que las ficciones son instrumento o «arte insuprimible de la actividad intelectiva del hombre ${ }^{147}$-idea ya sugerida por la antigua consideración de que fictio est interpretatio-, el recurso a las mismas es bastante corriente en el discurso de los juristas y en la composición de la normativa del mismo ordenamiento positivo ${ }^{148}$, considerando en ellas a lo existente

${ }^{143}$ Sobre la venta en garantía puede verse, entre otras muchas, la STS. de 8 de marzo de 1963. En nuestra doctrina es de destacar la monografía de Vidal MARTínez, La venta en garantía en el derecho civil común español, Madrid, Cívitas, 1990.

${ }^{144}$ Se aprovechan en el texto expresiones de la STS. de 4 de julio de 1998 -que a su vez las toma de la STS. de 2 de diciembre de 1996-, que califica la combinación que describe como «la verdadera esencia de todo negocio fiduciario... (trátese de fiducia cum amico o de fiducia cum creditore)».

145 Cfr. Legendre, Il giurista artista de la ragione cit., pág. 49.

146 Cfr. Legendre, Il giurista artista della ragione cit. pág. 212.

147 Cfr. Alpa, Le finzioni giuridiche, en Trattato di diritto civile (dir. Sacco), 2. Le fonti non scritte e l'interpretazione, Torino, Utet, 1999, págs. 334 s.

148 A propósito de las ficciones me permito remitir a Luna SERrano, Las ficciones del derecho en el discurso de los juristas y en el sistema del ordenamiento (discurso de ingreso, como académico numerario, en la «Acadèmia de Jurisprudència i Legislació de Catalunya», leído el día 27 de enero de 2004), Barcelona, 2004. De esta obrita hay traducción al italiano, cuidada por el abogado Andrea DonATI, bajo el título de Le finzioni nel diritto (con presentación del profesor Alberto DonATI), Perugia, 2008, un vol. de 144 páginas. 
«como si» no existiera o a lo inexistente «como si» existiera. Las ficciones a que se recurre en el derecho son, en efecto, lo mismo ficciones doctrinales que ficciones convencionales y lo mismo ficciones jurisprudenciales como, sobre todo, ficciones legales. De ahí que el tema de las ficciones constituya uno de los tópicos o lugares comunes de la teoría general del derecho. En todos los supuestos de ficción se persigue una cierta finalidad práctica cuyo logro se alcanza mediante el establecimiento, la fijación o la determinación de unos hechos que se llegan a obtener mediante la interesada formalización de una verdad artificial a costa de abandonar la verdad histórica o material ${ }^{149}$.

Dejando aparte las ficciones doctrinales, las convencionales y las jurisprudenciales -de cuyas últimas la más llamativa ha sido en su día la denominada «ficción de hembra» construida por el Tribunal Supremo ${ }^{150}$-, las ficciones legales se encuentran en los más variados campos normativos de que se compone el sistema del ordenamiento. Así ocurre en el derecho administrativo con el «silencio positivo o negativo» ${ }^{151}$, en el derecho penal con el «delito continuado», en el derecho internacional con los «edificios extraterritoriales» o con la «territorialidad» en alta mar o en el espacio aéreo abierto de los buques abanderados o de las aeronaves de bandera o, en el derecho tributario, las normas del cual están cuajadas tanto de presunciones como de ficciones ${ }^{152}$, pero aquí sólo se hará mención, en aras de la brevedad, a algunas de las ficciones a las que recurre el Código civil.

En relación a la persona en sí misma se encuentran en el Código dos clásicas ficciones: la primera, de ascendencia romana, es la de considerar

149 Aunque, como afirmaba Baldo, auctoritas legis non potest veritatem tollere $\mathrm{y}$, como sentenciaba una regula iuris communis, la fictio cessat ubi veritas locum habere potest, la consideración de la fictio legis como «verdad oficial» productora de «certeza» se hizo habitual entre los juristas, señalando el gran Cujaccio que de ordinario fictio legum veritate potentior est: plus potest quam veritas, y el no menos famoso Donello que fictio tantum valet quantum veritas. Este carácter de «verdad oficial» de la ficción se evidencia también en el viejo brocardo según el cual fictio (iuris) operatur quod veritas.

${ }^{150}$ Me refiero a la polémica STS. de 2 de julio de 1987, en relación a un supuesto de la llamada transexualidad.

151 En relación a la figura del silencio administrativo, la STC. de 17 de junio de 2009 lo califica de «ficción legal» que responde a la finalidad de que el administrado pueda acceder a la vía judicial superando los efectos de la actividad de la Administración.

De las ficciones en derecho administrativo, puede verse, últimamente, BLANQUER, Hechos, ficciones, pruebas y presunciones en el derecho administrativo. "Taking facts seriously», Valencia, Tirant lo Blanch, 2006.

${ }^{152}$ La literatura sobre las ficciones en el derecho tributario es bastante copiosa: vid., entre otros, Pérez De Ayala, Las ficciones en el derecho tributario, Madrid, Editorial de Derecho Financiero, 1970, y MARTín-BARnUevo, Presunciones y técnicas presuntivas en derecho tributario, Madrid, Mc. Graw-Hill, 1996. 
nacido al nascituro ${ }^{153}$ y la segunda la que establece que el domicilio de los diplomáticos que sirven en el extranjero es el último que han tenido en territorio español ${ }^{154}$. También puede considerarse una ficción la llamada presunción de comoriencia, en cuanto que su presupuesto es precisamente, contra lo que ocurre en el caso de las presunciones, que no sea posible ningún tipo de prueba sobre quien murió primero de dos personas que mueren, por ejemplo, en el mismo accidente ${ }^{155}$. En relación al matrimonio, también se decreta legalmente la ficción de que la condición, el término o el modo que se han puesto se consideran como no puestos ${ }^{156}$. Por lo demás, entre las instituciones que manifiestan con mayor claridad la divergencia entre la realidad y el derecho hay evidentemente que citar, según una compartida y autorizada doctrina, a la adopción ${ }^{157}$.

Por lo que se refiere a los bienes, un caso ejemplar de ficción está constituido por la catalogación de los bienes inmuebles, de los que se enumeran diez tipos, no siendo más que uno de ellos referible a cosas verdaderamente inmuebles e indicándose otros varios que sólo son inmuebles por razón de pura ficción, al punto, verbi gratia, de considerar bienes inmuebles a las concesiones administrativas ${ }^{158}$. Siempre en relación a los bienes son de particular interés ciertas ficciones relacionadas con su posesión y su adquisición: a este respecto se pueden citar el supuesto ficticio de la llamada «posesión civilísima» o transmitida al heredero sin interrupción y desde el momento de la muerte del causante ${ }^{159}$, que ha dado lugar por cierto al pleito económicamente más importante suscitado en España ${ }^{160}$; la norma que obliga a en-

${ }^{153}$ Cfr. art. 29 Cc.

154 Cfr. art. 40, 2 Cc.

155 Cfr. art. $33 \mathrm{Cc}$.

156 Art. 45.2 Cc.

157 Véase en tal sentido y con palabras semejantes LouIs-LuCAs, Verité matérielle et verité juridique cit., pág. 591.

Se ha hablado, en efecto, a propósito de la adopción de la diversificación entre una «verdad biológica» y una «verdad convencional», en la que la «familia de los afectos» vendría a sustituir a la familia biológica: cfr. MAzzù, La famiglia degli afetti, en Diritto Privato. Studi in onore di Antonio Palazzo, 2 (a cura di Mazzarese e Sassi) cit., págs. 527-559, esp. pág. 549.

${ }^{158}$ Cfr. art. 334 Cc.

${ }^{159}$ Cfr. art. 440 Cc. A la posesión civilísima, calificada como ficticia, hacen referencia, en relación a la usucapión de títulos nobiliarios, las STS. de 3 de noviembre de 2009 y de 13 de diciembre de 2010, la última de las cuales precisa que tal posesión, en razón de ser ficticia, carece de eficacia legitimadora frente a una posesión legal, real y efectiva.

160 Se hace referencia en el texto al conocido asunto de «La Canadiense» o de «La Barcelona Traction», en el que intervinieron, como abogados o como dictaminantes, las más prestigiosas figuras de la época de la cátedra y del foro. 
tender que la parte del bien que se divide y que se entrega a cada uno de los partícipes en la comunidad ha sido individualmente poseído mientras dura la indivisión ${ }^{161}$; o bien los supuestos de la llamada ficta traditio, pensados por nuestro legislador ${ }^{162}$ para atenuar la rigidez de la aplicación mecánica de la llamada teoría del título y el modo en la transmisión de la propiedad ${ }^{163}$. Otros supuestos de ficción, siempre fundamentados en la equidad, se refieren en tema de derechos reales a la ficticia subsistencia del usufructo extinguido objeto de hipoteca y a la ficticia subsistencia independiente de los reunidos derechos de propiedad del suelo y de superficie sobre los que recae un gravamen $^{164}$.

En materia de obligaciones y contratos se establece ficticiamente que la condición de hacer una cosa imposible se tiene por no puesta ${ }^{165}$, que los efectos de la obligación condicionada de dar se retrotraen, una vez cumplida la condición, al día de la constitución de la obligación ${ }^{166}$ o bien que está cumplida una condición cuando el obligado por ella impide su cumplimiento ${ }^{167}$.

En tema de derecho sucesorio, y en cuanto a las condiciones testamentarias, han de entenderse ficticiamente por no puestas las condiciones imposibles y las contrarias a las leyes o a las buenas costumbres así como la costumbre absoluta de no contraer matrimonio ${ }^{168}$. Siempre en materia sucesoria, una interesante ficción es la de entender que tienen efectos retroactivos al momento de la muerte del causante la aceptación o la repudiación de la herencia ${ }^{169}$.

Aunque algunos discuten su equiparación, es posible considerar asimilables a las ficciones las llamadas presunciones iuris et de iure, frente a las cuales no cabe prueba en contrario y respecto de las cuales no puede decirse, como en el caso de las presunciones iuris tantum, que sean «verdades provisionales» sino que, lo mismo que las ficciones y aunque no respondan a la

${ }^{161}$ Cfr. 450 Cc.

162 Cfr. arts. 1462.2 y 1463 Cc.

163 Cfr. art. 609 Cc.

${ }^{164}$ Cfr. sobre estos puntos el art. $107,1^{\circ}$, Lh. y art. 41.5 de la ley 8/2007, de 28 de mayo de suelo. Sobre los aspectos mencionados me permito remitir a Luna SERrano, Las ficciones legales y los derechos reales, trabajo en curso de publicación en el volumen de estudios en honor del prof. Antonino Cataudella.

165 Cfr. art. $1166.2 \mathrm{Cc}$.

166 Cfr. art. 1120 Cc. Observa justamente Louss-LucAs, Verité matérielle et verité juridique cit., págs. 593 s., que «decir que un acontecimiento que se produce en una determinada fecha se tiene por producido anteriormente»... es una fórmula que «hostiga el sentido más elemental de la verdad».

167 Cfr. art. 1119 Cc.

168 Cfr. arts. 792 y 793 Cc.

169 Cfr. art. 989 Cc. 
realidad, se constituyen en derecho como «verdades definitivas», por lo que deben considerarse como «ciertas». Sirvan al efecto dos supuestos presentados como presunciones que en realidad configuran verdaderas ficciones, en cuanto que, como el ordenamiento no consiente saber si responden o no a la verdad, se deben aceptar y tener, aunque sean «falsas», como si fueran «ciertas». El Código civil establece, en este sentido, que se presume siempre hecha una donación en fraude de acreedores, si al hacerla no se ha reservado el donante bienes para pagar sus deudas anteriores ${ }^{170}$ e igualmente establece la presunción de que incurren en fraude de acreedores las enajenaciones hechas a título gratuito por el deudor ${ }^{171} \mathrm{y}$, por su parte y de manera aún más radical, la legislación concursal establece, respecto de las donaciones en perjuicio de la masa activa del conjunto de los derechos de los acreedores, que dicho perjuicio, aunque no exista, se presume, sin admitirse prueba en contrario, cuando se trate de actos de disposición a título gratuito y de pagos $\mathrm{u}$ otros actos de extinción de obligaciones cuyo vencimiento fuera posterior a la declaración del concurso ${ }^{172}$.

\subsection{Las verdades falsas.}

Por lo demás, y del modo indicado, si es claro, desde luego, que hay hechos a los que el ordenamiento reconoce «certeza» porque, según ocurre de ordinario, responden a la «verdad», también es perfectamente posible que el ordenamiento contemple como «ciertos» hechos que, en definitiva y mediante comprobación a posteriori, pueden resultar ser «verdades falsas» o que ya son «verdades falsas» a priori pero que el ordenamiento no permite o ya no consiente desvirtuar. A pesar de ello y todo y ser falsos, tales hechos constituirán «certezas» desde el punto de vista del derecho positivo.

Al margen de los casos, no imaginarios, de irregularidades respecto de la producción normativa que, por obvias razones de simplicidad y de certeza, no se tienen en cuenta aunque encierren una falsedad ${ }^{173}$, basta pensar en las

${ }^{170}$ Cfr. art. 643.2 Cc.. Como de manera a la vez razonable, tajante y sencilla explica la STS. de 9 de noviembre de 1966, «si el deudor, cuando lleva a cabo los actos dispositivos y especialmente -como en el caso de autos- la donación en pro de sus hijos, no dejó en su patrimonio bienes suficientes para responder de las deudas anteriores a ella, es obligada la aplicación de la presunción de fraude con respecto de dicho contrato de donación.

171 Cfr. art. 1297 Cc. La STS. de 18 de enero de 1991 precisa adecuadamente que la presunción establecida en este precepto tiene el carácter de praesumptio iuris et de iure y, en la misma dirección, la STS. de 16 de febrero de 1993, declara igualmente que la presunción de fraude establecida tanto en este precepto como en el anteriormente citado art. 643.2 Cc. es una presunción iuris et de iure, «es decir, que no admite prueba en contrario».

${ }^{172}$ Cfr. art. 71.2 de la ley 22/2003, de 9 de julio, concursal.

173 Como promulgarse una ley con la sanción de una firma extendida en Madrid por quien se encuentra en Suiza en la fecha de tal suscripción o de no publicarse una norma 
verdades presuntas que no se corresponden con la realidad pero que, por no presentarse frente a la presunción iuris tantum que las sostiene una prueba contraria que las desvirtúe, pasan de ser «verdades provisionales», aunque sean falsas, a ser «certezas» o "verdades definitivas»; en las verdades aparentes, que no son reales pero que, cuando generan la confianza ajena, el ordenamiento tiene definitivamente por ciertas; en las verdades simuladas que se mantienen como verdaderas, bien porque así se desea por los interesados o bien porque quien quiere desmentirlas ha perdido la ocasión ${ }^{174} \mathrm{o}$ carece de prueba para denunciarlas; o también en las verdades ficticias en las que la mentira es evidente; o en las verdades amparadas por presunciones iuris et de iure, que hay que soportar necesariamente aunque se sepa que no se corresponden con la verdad; o, asimismo, en las verdades fiduciarias, que por necesidad conceptual no se corresponden con la realidad, pero que aparecen como verdaderas y generan «certeza» mientras los que las constituyen y crean están interesados en que permanezcan; o en los casos en que un hombre se hace aparecer legalmente, constando como tal en el registro civil, como mujer, en razón del llamado «sexo psicosocial»»" casos en que legalmente se atribuye, al margen del caso de la adopción, la condición legal de padre a quien ciertamente no lo es desde el punto de vista biológico, por haber sido sometida su esposa o conviviente a las técnicas de procreación médicamente asistida con inseminación heteróloga; o incluso en el caso, más llamativo, de la atribución de la condición legal de madre a la mujer casada civilmente con la mujer inseminada que da a luz un hijo concebido artificialmente, constituyéndose así un caso de doble maternidad, en parte no biológica sino legal ${ }^{176}$.

según el procedimiento establecido sino, como ha ocurrido en alguna ocasión, a través del socorrido recurso de la «corrección de errores materiales» en el periódico oficial. A defectos de este tipo se refiere, de manera genérica e incidentalmente, JoRI, Il formalismo giuridico, cit., pág. 68 , n. 53, que señala que ordinariamente la regularidad de los actos de producción normativa se «presume» por las razones aludidas en el texto.

${ }^{174}$ La posibilidad de restablecer la «verdad biológica» en el supuesto de los reconocimientos de complacencia podría intentarse bien en razón de la alegación de vicios de la voluntad del recognoscente (art. $141 \mathrm{Cc}$.) -en casos eventualmente de violencia o de intimidación, pero no evidentemente alegando error- $\mathrm{o}$ bien mediante acción de aquellos a los que el reconocimiento perjudica o también en supuestos de alternativa posesión de estado (art. 140 Cc.), pero tal impugnación ha de hacerse dentro del plazo de caducidad de cuatro años a que se refiere el último de los preceptos: cfr., últimamente, STS. de 29 de noviembre de 2010.

${ }^{175}$ Cfr. la ley 3/2007, de 15 de marzo, reguladora de la rectificación registral de la mención relativa al sexo de las personas.

176 Todo ello es posible en función de lo dispuesto en la ley 14/2006, de 26 de mayo, de técnicas de reproducción humana asistida (art. 7.3, apartado añadido por la ley 3/2007, de 15 de marzo, reguladora de la rectificación registral de la mención relativa al sexo de la persona). Téngase en cuenta además que en el caso de inseminación heteróloga está asegurado legalmente el anonimato del donante del material genético masculino (art. 
En el aludido caso de la adopción, aparte del supuesto habitual de ser jurídicamente considerados como padre y madre los adoptantes que biológicamente no lo son, como la eventual «determinación de la filiación que por naturaleza corresponda al adoptado no afecta a la adopción» ${ }^{177}$, podría darse la paradójica situación de que los adoptantes, que no son biológicamente progenitores, sean considerados jurídicamente como padres y de que, contemporáneamente, quienes biológicamente lo son, de manera comprobada, dejen de ser, por regla general ${ }^{178}$, considerados por el derecho como tales ${ }^{179}$.

5.5), con lo que, en contradicción con lo que postula el art. 39.2 de la Constitución, se impide la investigación de la paternidad mediante pruebas biológicas.

Los supuestos indicados en el texto han sido eficazmente señalados como supuestos de «desbordamiento de la biología por el derecho» por Martínez de AGuirRe y Aldaz, La filiación, entre biología y derecho, en «Homenaje a Victor Manuel Garrido de Palma», Cizur Menor, Cívitas-Thomson, 2010, págs. 819-852, esp. págs. 836 ss. Este mismo autor señala (págs. 838 y 852) la RDRN de 18 de febrero de 2008 que consiente la inscripción como hijos de los solicitantes - dos varones españoles que contraen matrimonio civil en nuestro país- de dos niños engendrados mediante un contrato de gestación por sustitución celebrado en California y que está prohibido en España: en este caso se da un supuesto de doble paternidad evidentemente falsa desde el punto de vista biológico. Posteriormente, una instrucción de la Dirección General de los Registros y del Notariado de 5 de octubre de 2010, sobre régimen registral de la filiación de los nacidos mediante gestación por sustitución, admite que, para dar lugar a la correspondiente inscripción, basta con que se presente una resolución judicial del país de origen (en que se ha concertado la prestación del llamado «vientre de alquiler») que garantice la legalidad del proceso.

177 Cfr. art. 180.4 Cc.

${ }^{178}$ Cfr. art. 178.1 Cc., que determina que la adopción extingue «los vínculos jurídicos entre el adoptante y su familia anterior». La RDGRN. de 25 de octubre de 1997 declara, en consecuencia, que a los efectos de la obtención de una certificación literal de nacimiento que refleje la adopción «los parientes por naturaleza del adoptado, incluidos los propios progenitores, son asimilados a los terceros»».

${ }^{179}$ De esta regla general del vínculo con la familia de origen se exceptúan el caso, más bien raro, de que el adoptado sea hijo biológico del cónyuge del adoptante y el supuesto de que «sólo uno de los progenitores haya sido legalmente determinado, siempre que tal efecto - la subsistencia del vínculo legal con la familia de origen- hubiera sido solicitado por el adoptante, el adoptado mayor de doce años y el progenitor cuyo vínculo haya de persistir»: cfr. art. 178.2 Cc., redactado conforme a la ley 13/2005, de 1 de julio, por la que se modifica el Código civil en materia de derecho a contraer matrimonio.

En estos casos habría jurídicamente lugar a la convivencia de dos diferentes filiaciones paralelas y sólo prácticamente convergentes: una, la adoptiva, que respondería a la «verdad convencional» y otra, la derivada de la determinación del vínculo originario de sangre, que respondería a la «verdad biológica». La STS. de 27 de junio de 1987 se refiere, en relación a un supuesto que se corresponde con el aquí considerado -en el sentido de establecerse posteriormente a la adopción la filiación biológica del adoptado-, que en tal caso no sólo tiene lugar «la posibilidad de que con posterioridad al hecho de la adopción se determine la naturaleza o familia sanguínea del adoptado, sino, también y obviamente, 


\section{APRECIACIONES CONCLUSIVAS.}

\subsection{La razonable divergencia entre certeza y verdad.}

Como se ve, certeza y verdad no necesariamente coinciden en el derecho $^{180}$, de manera, además, que es a veces difícil tomas partido, en derecho positivo, entre las dos exigencias de verdad y de seguridad que pueden enfrentarse entre si ${ }^{181}$.

Ello es así, sencillamente, porque el ordenamiento -cuya función es organizar como mejor puede y sabe la vida social- es un conjunto de reglas y de soluciones que se expresan mediante palabras y porque con la palabra pueden hacerse, cuando así conviene -en nuestro caso para generar «certeza»y «seguridad» a los consociados ${ }^{182}$ - toda suerte de figuras, de contrafiguras, de combinaciones, de metamorfosis en que lo falso toma el disfraz de lo cierto e incluso de mixtificaciones. En este sentido, aunque se puede, desde luego, pensar que las «certezas» o verdades oficiales a que se ha venido haciendo referencia no suponen sino la aceptación conformista y resignada de la autoridad del legislador, en cuanto que poco o nada tienen que ver con las seguras «verdades» que se derivan de la realidad y que son descubiertas por la ciencia y por la razón ${ }^{183}$, también hay que reconocer que

que persiste el lazo preexistente entre el mismo y su familia natural», coexistiendo, en el sentido indicado, por una parte la filiación adoptiva y, por otra parte, la filiación biológi$\mathrm{ca}$, ambas legalmente establecidas.

${ }^{180}$ Como subraya López de OÑATE, La certezza del diritto cit., pág. 51, la certeza del derecho alcanza particular relieve en el ámbito del derecho penal, en el que «este particular carácter del derecho que consisten en la necesidad de la certeza se presente con una particular evidencia, en razón de la más aguda y rígida fisonomía de tal rama del derecho». En el mismo sentido, CARNELUTTI, La certezza del diritto cit., pág. 195, señala que «se v'è un settore del diritto rispetto al quale la certezza assuma un valore di primo piano, questo è il diritto penale; così alto valore da aver ispirato quel riconoscimento legislativo del principio nullum crimen sine legge». De este fundamental perfil que es propio de la certeza en el derecho penal son expresión el art. 25.1 Const., los arts. 1 y 2 Cpen., el art. 1 Lecrim. y el art. 4.2 Cc.

181 Tomo aquí expresiones de TERRÉ, Introduction général au droit, Paris, Dalloz, 1991, § 492, pág. 402, formuladas al tratar de la prueba de los hechos.

${ }^{182}$ La relación entre la norma cognoscible y la seguridad jurídica es subrayada habitualmente por los juristas, que suelen pensar, en efecto, que, aunque imperfectas, las leyes tienen la finalidad de proporcionar certeza, siendo por ello necesarias ad civiles hominum actiones, societatemque civium ordinandam, quae sine huiusmodi gobernaculo statim corrueret, según palabras dirigidas en 1726 al emperador austriaco Carlos VI, a quien precisamente proponía una reforma encaminada a la mejor manifestación y más perfecta aplicación del derecho, por el reformista Muratori, De Codice carolino sive de novo legum codice istituendo, en Scritti politici postumi (a cura di B. Donati), Bologna, 1950, pág. 7.

183 Tal es la opinión de Opocher, Lezioni di filosofia del diritto cit., pág. 6. 
tales «certezas» se insertan instrumentalmente, sin mayor dificultad, como útiles mecanismos de la eficiencia del complejo entramado director de la vida social -pleno de claroscuros e imperfecto como toda obra humana-que es el ordenamiento jurídico. Ocurre, en efecto, que las normas se constituyen con frecuencia sobre una mezcla de variados elementos en que se funden y combinan los datos de la vida que emergen de la realidad natural o social con invenciones y construcciones artificiales que contribuyen a posibilitar las consecución más perfecta o más directa de la justicia ${ }^{184}$.

Sería ciertamente de desear que el derecho, en la búsqueda del equilibrio que conviene a la organización social para su conservación y su perfeccionamiento, encontrara algún tipo de acuerdo estable y constante entre los testimonios de la realidad material y las solicitaciones que surgen de la sociedad, pero seguramente tal unificación es poco concebible «en cuanto que uno de sus términos -el respeto de los hechos- es fijo y preciso, mientras que el otro -las necesidades de la sociedad- es movedizo y discutible» ${ }^{185}$. En este contexto se plantean, cada vez más, en el derecho, supuestos en que la dicotomía entre «verdad real» o «verité sans phrase» y «verdad oficial»o «verdad legal» ${ }^{186}$ o la contraposición entre «naturalidad»y «artificialidad» - disyuntiva esta última no desconocida, desde luego, a nivel doctrinal ${ }^{187}$ - se presentan, incluso a veces de manera radical, como legalmente poco superables ${ }^{188}$.

${ }^{184}$ Cfr., por referencia a Vassalli, Arte e vita nel diritto civile, en Studi giuridici, II, Milano, 1960, págs. 399 ss., Ferri, Filippo Vassalli o il diritto civile come opera d'arte, Padova, Cedam, 2002, págs. $116 \mathrm{~s}$.

185 Cfr. Louis-Lucas, Verité matérielle et verité juridique cit., págs. 594 s.

Puede señalarse a propósito, por lo demás, que en filosofía se ha distinguido, a veces, entre la «verdad de razón» y la «verdad de hecho» y que, de alguna manera, se podrían apreciar en las indicaciones que se hacen en el texto, aunque traslaticiamente, reflejos que se acercan a las categorías diferentes que son propias de la denominada «lógica de la verdad» o «truth-logic» y de la llamada «lógica de las modalidades» o «model logic», que tiene un carácter acusadamente formal: vid., para una breve aproximación a estas cuestiones, Boвbio, Contributi ad un dizionario giuridico, Torino, Giappichelli, 1994, págs. 141 s. (s.v. «Logica giuridica II») y 303 (s.v. «Ragione e diritto»).

186 Utilizo aquí expresiones de Romano TASSONE, Amministrazione pubblica e produzione di «certezza» cit., págs. 29 y 31, que se refiere también al «social impact» del acto productor de certeza.

187 Véase, por ejemplo, el enjundioso estudio de Donati, «Homo»e «persona». «Inherent dignity» e «Menschenwürde», en Atti dell'Accademia Romanistica Costantiniana, XVII, Perugia, 2010, págs. 73 a 236.

188 Véanse, a este propósito, últimamente, Busnelli, La persona alla ricerca dell'identità, en Rivista Critica del Diritto Privato, XXVIII-1 (marzo 2010), págs. 7 a 22, y Donati, Diritto alla propria identità: verso l' "absolute individual right»?, en Vita Notarile, 2011-1 (gennaio-aprile), págs. 3 a 18. 
El derecho, en efecto, no sólo cambia y se desenvuelve sino que en su evolución se sirve de recursos como las examinadas verdades oficiales, cuya técnica no es, por lo demás, en absoluto novedosa, puesto que hasta hace relativamente poco tiempo se conoció una categoría tan sorprendente como la «muerte civil», que daba por muerto para el derecho a quien seguía viviendo, y ahora se permite, como hace nuestro derecho, cambiar al hombre en mujer o se consiente, como en el derecho francés, ya que no resucitar a los muertos, al menos que puedan, con posterioridad a su muerte, contraer póstumo matrimonio ${ }^{189}$.

\subsection{Colofón.}

En definitiva, el derecho adopta una postura de cierta relatividad en relación con la verdad, en cuanto que, si ésta, como objetividad material, sólo puede calificarse como tal cuando es verificada con exactitud, la realidad jurídica se cifra, en cambio, en el carácter de su efectividad, lo que la hace en definitiva consistir en una "certeza» reformulada o imaginada, en el sentido de que puede coincidir o no con la verdad histórica, objetiva o material ${ }^{190}$.

Esto es así porque el derecho tiene en cuenta, desde luego, la tensa amalgama que muestra el complejo entramado vital e intersubjetivo -intereses, acontecimientos, relaciones- que tiende a encauzar, de modo que, para organizar eficazmente la vida social, necesita formalizar amplios segmentos de

189 En efecto, el art. $171 \mathrm{Cc}$. fr., repristinado en su redacción actual por la ley de 31 de diciembre de 1959, otorga al Presidente de la República la facultad de autorizar, por motivos graves, la «celebración del matrimonio» si uno de los futuros esposos ha fallecido después de cumplirse las formalidades oficiales indicando inequívocamente su consentimiento. La razón de la admisión legal de este matrimonio ficticio, que no entrañaría derecho sucesorio ab intestato alguno a favor del esposo superviviente, se encuentra en la posible legitimación, mediante este matrimonio póstumo, del hijo natural nacido después de la muerte de su padre. Es de notar que el precepto, siempre recurriendo a la técnica de la ficción, establece que los efectos de este matrimonio póstumo se retrotraen a la fecha del día anterior a la muerte del esposo.

La tradición solía entender, en cambio, que había situaciones o relaciones contempladas por las normas cuyos efectos no se podían, por el carácter de su entidad, legalmente modificar o suprimir: así por ejemplo, HiEnNECCIUs, Elementa iuris secundum ordinem Institutinum (trad. fr. de Berthelot con texto latino al frente) ( $2^{\mathrm{a}}$ ed.), I, París, Terdieu Denesle et Cie., 1812, § 222, págs. 220 s., observaba, explicando las figuras de la agnación y de la cognación, que los efectos de la agnatio podían decaer porque era una civilis qualitas, pero no lo de la cognatio, porque ésta era una qualitas naturalis. Y hasta hace poco era manifestación del mismo pensar la afirmación habitual de que el parlamento inglés podía hacerlo todo menos convertir a un hombre en mujer.

190 Tomo estas ideas y algunas de las expresiones utilizadas últimamente en el texto de Louss-Lucas, Verité matérielle et verité juridique cit., pág. 601. Recuérdese a este propósito, la calificación del derecho como «hermenéutica oficial del mundo» a que se hace referencia en la n. 12 . 
esa realidad humana y a tal efecto los conforma con gran plasticidad, según le conviene, de acuerdo con las técnicas y los instrumentos que la historia le propone, con las fórmulas que las urgencias sociales, las nuevas realidades o las opciones políticas le exigen o sugieren o incluso, muchas veces, como puede.

No puede desconocerse, sin embargo, que el mayor y más deletéreo riesgo que entraña la potencial divergencia entre la certeza legal y la verdad sustancial es que la misma supere el nivel instrumental o puramente técnico en el que estas páginas han pretendido mantenerse y abra la puerta a la actitud relativista de caer en el nihilismo jurídico, que, como fácil derivación consecuente del positivismo, se difunde insidiosamente -en cuanto que frecuentemente ni siquiera es advertida su persistente infiltración- entre no pocos juristas de nuestros días. Nihilismo, por otra parte, que favorece la implantación de ciertas opciones de configuración de la sociedad y del que se sirven ciertos poderes económicos y políticos, a cuyos decididos intentos de ingeniería social ayuda poderosamente la idea, bastante difundida entre los legisladores y acrítica y pasivamente aceptada por muchos juristas que los secundan, de que la ley puede tener cualquier contenido y de que éste, por el hecho de estar previsto -aunque de manera casual y contingente- en la ley que determina «certeza», ha de ser considerado y admitido como la única verdad, aunque la misma sea efímera, ya que se piensa, en tal planteamiento, que las leyes vienen de la nada y vuelven a la nada ${ }^{191}$.

\section{TITLE: Certainty and truth in Law.}

RESUMEN: Este artículo analiza la relación entre la verdad natural y la verdad jurídica. Lo que el derecho dice y afirma como cierto, en función

${ }^{191}$ Aprovecho aquí alguna expresión tomada de PerLINGIERI, El derecho civil en la legalidad constitucional según el sistema italo-comunitario de las fuentes (trad. esp., coord. por Luna Serrano y Maluquer de Motes y Bernet, de la $3^{\mathrm{a}}$ ed. it. de 2006), Madrid, Dykinson, 2008, pág. 134, en el apartado significativamente intitulado «insidias del nihilismo: razones del mercado y razones del derecho», que es un resumen de una contribución más amplia, del mismo título y en lengua italiana, aparecida en Rassegna di diritto civile, 2005, págs. 3 ss.

Sobre el nihilismo jurídico puede verse, como fundamental, la importante contribución de IrTI, Il nichilismo giuridico, Bari, Laterza, 2004. Sobre las causas, remotas y próximas, el sentido, la significación y la transcendencia del nihilismo jurídico, puede verse la profunda reflexión crítica de Donati, Diritto naturale e globalizzazione, Roma, Aracne, 2007, y también Donati, Giuspositivismo e nichilismo giuridico, en Vita notarile, 2008, págs. 1201 ss.; y, en otra perspectiva, BARCELlona (M.), Crítica del nichilismo giuridico, Torino, Giappichelli, 2006.

Para una introducción filosófica al nihilismo puede verse, en un análisis de carácter general, el libro de Volpi, Il nichilismo (3 ${ }^{\mathrm{a}}$ ed.), Bari, Laterza, 2005 (hay trad. esp. de DeL Rosso y G. Vigo, Madrid, Siruela, 2007). Puede verse también Vercellone, Introduzione al nichilismo, Bari, Laterza, 1992. 
de su autoridad, no siempre se corresponde con la verdad, que se percibe o se descubre por la razón. Así, si bien en la mayoría de los casos el ordenamiento dispensa seguridad a través de la certeza que se deriva de la realidad de una manera directa y natural, no faltan ocasiones en que las leyes crean ellas mismas esa realidad jurídica.

Palabras CLAVE: Seguridad juridica, Derecho, Estado de Derecho.

ABSTRACT: This article analyzes the relationship between natural truth and legal truth. What the law says and affirms as true, according to his authority, does not always correspond with the truth, perceived or discovered by reason. Thus, although in most cases the ordering security waiver by the certainty that comes from reality in a direct and natural, not lack opportunities that laws themselves create legal reality.

KEY WORDS: Legal certainty, Law, Rule of Law.

Recibido: 06.09.2012

Aceptado: 18.01.2013 